\title{
DUNCAN V. BADDELEY: A CASE COMMENT'
}

\author{
CARA L. BRown, M.A.
}

\section{INTRODUCTION}

At present, Alberta law allows the estate of a deceased individual to pursue a claim for the deceased's loss of a chance of earnings ${ }^{2}$ under s. 5 of the Survival of Actions Act. ${ }^{3}$ Claims of this nature are a relatively new development in Alberta tort law, and this article will attempt to demarcate the accepted method of assessing loss of a chance of earnings under the Survival of Actions Act in light of Duncan v. Baddeley ${ }^{4}$ and recent trends in case law - special attention will be paid to clarifying conflicting approaches for calculating the deduction for personal living expenses, also known as the "lost years" deduction. ${ }^{\text {s }}$

A claim by the deceased's estate for his or her loss of a chance of earnings is differentiated from a claim made by the deceased's dependents for their loss of dependency on the deceased's earnings - the latter claim is pursued under s. 3 of the Fatal Accidents Act.

This article is not aimed to simply echo the remarks of the majority in the Alberta Court of Appeal's decision in Duncan (C.A.) or to rebut the suggestions of the Alberta Law Reform Institute in its December, 1998 report, Should a Claim for the Loss of a Chance of Earnings Survive Death?, ${ }^{7}$ which questioned the policy implications of loss of future earnings claims pursued by estates under Alberta's Survival of Actions Act.

With assistance from Andrea Beckwith, B.A., LL.B. Ms. Brown is the Principal and founder of Brown Economic Assessments Inc., Calgary, Alberta. Ms. Brown provided expert economic evidence on behalf of the Plaintiff in Duncan v. Baddeley, [1999] A.J. No. 107 (Alta. Q.B.) (QL). This article is the continuation of C.L. Brown, "Duncan v. Baddeley: Reconciling the 'Lost Years Deduction' with Fatal Accident Cases" (1997) 35 Alta. L. Rev. 1108.

The case law and literature regarding claims of this nature use the phrases "loss of earnings" and "loss of a chance of eamings" interchangeably. In this paper, the phrase "loss of a chance of earnings" will be used.

R.S.A. 1980 , c. S-30.

Duncan Estate v. Baddeley, [1994] A.J. No. 870 (Alta. Q.B.) (QL); (1997), 145 D.L.R. (4th) 708 (Alta. C.A.) [hereinafter Duncan (C.A.)]; leave to appeal refused [1997] S.C.C.A. No. 315 (QL); [1999] A.J. No. 107 (Alta. Q.B.) (QL) [hereinafter Duncan (Q.B.)].

The author will use the phrase "lost years" deduction for the purposes of this article.

R.S.A. 1980, c. F-5.

Alberta Law Reform Institute, Should a Claim for the Loss of a Chance of Future Earnings Survive Death? (Final Report No. 76) (Edmonton: Alberta Law Reform Institute, 1998) [hereinafter Final Report No. 76].

This policy paper concentrated on the debate regarding whether "actual financial loss," as per s. 5 of the Survival of Actions Act, should include loss of a chance of future carnings. The section of the $A c t$ reads "If a cause of action survives under s. 2, only those damages that resulted in actual financial losss to the deceased or his estate are recoverable and, without restricting the generality of the foregoing, punitive or exemplary damages for loss of expectation of life, pain and suffering, physical disfigurement or loss of amenities are not recoverable." 
It is beyond the economist's scope of expertise to consult on the canons of construction and the rules of interpretation as they apply to survival legislation. Rather, it is incumbent on the expert economic witness to clearly outline the steps required to calculate a claim based upon the guidelines given in Duncan (C.A.) and given the current state of law in Alberta.

This article will also address the Duncan (Q.B.) decision vis-à-vis Belzil J.'s reasons for judgment in Brooks v. Stefura, ${ }^{9}$ the first case in Alberta to address the interrelationship between dependency loss claims pursued under the Fatal Accidents Act and Survival of Actions Act claims for loss of a chance of future earnings.

\section{DUNCAN V. BADDELEY}

\section{A. DUNCAN V. BADDELEY - A BRIEF History ${ }^{10}$}

While the head of damage "loss of a chance of future earnings" is a relatively recent development in case law, claims of this nature have been evolving since the inception of the Lord Campbell's Act (U.K.)" in 1846. Lord Campbell's Act was the forerunner to Alberta's current Fatal Accidents Act and permitted dependents to advance loss of dependency awards against tortfeasors.

England's 1934 Law Reform (Miscellaneous Provisions) Act (U.K.) ${ }^{12}$ was a more precise precursor to the current Survival of Actions Act, permitting the survival of actions for deceased individuals regardless of their death. Early cases such as Rose $v$. Ford, ${ }^{13}$ Benham v. Gambling, ${ }^{14}$ Flint v. Lovell, ${ }^{15}$ and Yorkshire Electricity Board v. Naylor ${ }^{16}$ set guidelines for the calculation of damages for loss of expectation of life under the Law Reform (Miscellaneous Provisions) Act (U.K.).

Pickett v. British Rail Engineering ${ }^{17}$ marked a turning point in the advancement of claims for loss of a chance of future earnings in wrongful death cases. In that case, the plaintiff was a man suffering from asbestos poisoning at the time of trial - he died after trial but before appeal. The Pickett Estate appealed for the loss of earning capacity suffered by the deceased. The House of Lords held that pre-accident working life expectancy is the benchmark to use when assessing damages for loss of earning capacity; accordingly, the court treated the claim by the Pickett Estate as though Mr. Pickett were still living at the time of appeal.

Brooks v. Stefura, [1998] 9 W.W.R. 312 (Alta. Q.B.) [hereinafter Brooks].

11 For a more comprehensive history regarding claims of this nature, see Brown, supra note 1.

" $9 \& 10$ Vict., c. 93

$12 \quad 25$ Geo. 5 , s. 41 .

13 [1937] 3 All E.R. 359 (H.L.).

14 [1941] I All E.R. 7 (H.L.).

is [1935] 1 K.B. 354 (C.A.).

$16 \quad$ [1968] A.C. 529 (H.L.).

17 [1979] I All E.R. 774 (H.L.) [hereinafter Pickett]. 
In Gammell v. Wilson, ${ }^{18}$ the House of Lords reaffirmed its decision in Pickett and allowed loss of a chance of future earnings claims for two young men who were wrongfully killed, leaving no dependents. In that case, the Court held that the 1934 Law Reform (Miscellaneous Provisions) Act (U.K.) permitted the deceaseds' estates to claim for loss of earnings. This decision was endorsed by the Australian High Court in Fitch v. Hyde-Cates. ${ }^{19}$

Alberta courts first considered a claim for loss of a chance of future earnings launched under the Survival of Actions Act in Galand Estate v. Stewart. ${ }^{20}$ Côté J.A. commented that

[s]ometimes an estate can and should recover for tortious loss of earnings or earning capacity of the deceased. One may compare Pickett v. British Rail Engineering, supra, where the plaintiff successfully sued for curtailed earnings from shortened life, and this was affirmed on appeal after his death. $I$ interpret the words "actual financial loss" in $s .5$ of the Act to cover at least some such cases....

I do not say whether such claims are good in the case of the death of young children without a job or other source of income. And if they are, 1 do not say whether the damages should be nominal, substantial, arbitrary, or capped. Nor do I say that the policy clash briefly referred to above is irrelevant to any of those questions. Those questions may be decided another day. They will be decided much better in cases with real evidence. ${ }^{21}$

The Galand Estate decision set the stage for Duncan v. Baddeley, wherein the deceased's estate advanced a claim for loss of a chance of future earnings. Accordingly, we now address the "real evidence" of Duncan v. Baddeley.

\section{B. Duncan v. Baddeley - The Facts}

The first ruling in Duncan v. Baddeley was released by Hembroff J. on 16 November 1994. The Plaintiff appealed that decision to the Alberta Court of Appeal and decisions were released on 27 March 1997 and 8 April 1997. The Court of Appeal returned the case to the Alberta Court of Queen's Bench for a quantum assessment. The Defendant appealed the Alberta Court of Appeal ruling to the Supreme Court of Canada, however leave to appeal was refused on 6 November 1997 (without reasons). Sulyma J. released a quantum decision for Duncan (Q.B.) on 2 February 1999.

In order to provide a backdrop for analysis of the Duncan v. Baddeley case, the following facts should be considered: ${ }^{22}$

- Dean Duncan was killed by the negligent acts of a tortfeasor;

[1981] 1 All E.R. 578 (H.L.).

(1981-82), 150 C.L.R. 482 (Aust. H.C.).

(1993) 4 W.W.R. 205 (Alta. C.A.) [hereinafter Galand Estate].

lbid. at 213 [emphasis added].

See C.I. Taylor, "Loss of Earning Capacity Claim Pursuant to the Survival of Actions Aci" (paper prepared for Lexpert Conference How Much is $/$ Worth? State of the Art Personal Injury Damages, 16 April 1999). Ms. Taylor and R. Haggett were the Plaintiff's co-counsel in this matter. 
- Dean Duncan was 16 years old at the time of his death, had a higher than average IQ, but had relatively unstructured career aspirations;

- Dean Duncan was unmarried and did not have any dependents at the time of his death;

- At the time of his death, Dean Duncan had no unusual health problems which would have affected his life expectancy;

- At the time of his death, Dean Duncan was a grade 11 student, held down a part-time job as a gas station attendant and had small savings in two bank accounts;

- Dean Duncan's parents are both employed and are successful in their respective careers; and

- Dean Duncan had one sibling, a younger brother, who was completing a Geology degree at the University of Alberta at the time of Sulyma J.'s 1999 Reasons for Judgment.

One should also note that when the Duncan v. Baddeley claim was launched in 1987, the beneficiaries of Mr. Duncan's estate were only entitled to $\$ 3,000$ for bereavement under the Fatal Accidents Act; with the 1 September 1994 amendments to the Fatal Accidents $A c t,{ }^{23} \mathrm{Mr}$. Duncan's beneficiaries, his parents, would have been entitled to $\$ 40,000$ for bereavement.

The parties to the action in Duncan v. Baddeley, agreed that:

- Dean Duncan would have earned $\$ 35,000$ per year (before taxes) from 1993 , the year of his expected entry into the workforce, until retirement at age $62-$ no wage growth would be applied to this figure;

- A discount factor of 3 percent would be used in the calculations;

- There would be no contingency deduction for the risk of mortality prior to retirement;

- There would be no application of a productivity factor to the calculations; and

- There would be an overall 5 percent deduction for contingencies, applicable against the amount arrived at after applying a "lost years" deduction, for personal living expenses to Dean Duncan's after-tax income. 


\section{Duncan v. Baddeley - An Economic Analysis}

As indicated above, the Alberta Court of Appeal set out a series of guidelines for calculating an award for loss of a chance of future earnings. Sulyma J. applied these guidelines in her Duncan (Q.B.) decision. Accordingly, this section will first address the quantum methodology outlined by the Alberta Court of Appeal and will then address Sulyma J.'s application of this methodology to the facts of the case in Duncan (Q.B.).

\section{Methodology ReCOMmended by Alberta COURT of APPEAL}

Kerans, Côté, and Lieberman JJ.A. all delivered separate reasons in Duncan (C.A.). Kerans J.A. delivered the majority judgment regarding the assessment of damages. Côté J.A. concurred with Kerans J.A. and added comments regarding the policy underlying Survival of Actions Act claims for loss of a chance of earnings. Lieberman J.A. delivered a dissenting opinion. This article will primarily focus on the commentary of Kerans J.A. regarding the quantum assessment for a "Duncan v. Baddeley type" claim.

\section{a. The Personal Living Expenses Deduction ${ }^{24}$}

One of the main distinguishing characteristics of the calculation for loss of a chance of earnings under the Survival of Actions Act from dependency loss calculations under the Fatal Accidents Act is the application of a "lost years" deduction in the former. ${ }^{25}$

The "lost years" can be defined as those years in which the deceased would be earning income (if alive) but is no longer alive to spend it because of the accident. The "lost years" are also applied to calculations for injured plaintiffs who can expect a shortened life expectancy because of the tortious act committed against them. Not surprisingly, most of the case law used by the Alberta Court of Appeal to determine an appropriate "lost years" deduction in Duncan (C.A.) involved injured plaintiffs rather than deceased individuals. Specifically, the Court of Appeal relied on ToneguzzoNorvell v. Burnaby Hospital, ${ }^{26}$ to support the notion that "[a] major adjustment to awards of this kind must be made for the off-setting savings during the expected life of the victim; for example, for the savings of personal living expenses." 27

See also Brown, supra note 1.

See C.L. Brown, "Wrongful Death Claims: Dependency Loss Calculations" (1999) Advocates' Q., forthcoming [hereinafter Wrongful Dealh Claims] for a discussion of the differences between loss of income calculations in personal injury cases, loss of dependency calculations in Fatal Accidents Act calculations, and loss of a chance of earnings calculations in Survival of Actions Act calculations. The "lost years" deduction is only applied to personal injury claims when life expectancy is shortened. Taxes are not deducted from the personal injury award, tax gross ups are not applied to the personal injury award, and loss of housekeeping capacity claims may be awarded in personal injury cases. In contrast, in Survival of Actions Act cases, the "lost years" deduction is always applied, income taxes are deducted from the award, it is not known whether tax gross ups are applicable to Survival of Actions Act claims, nor whether loss of housekeeping services claims are permissible under the Survival of Actions Act. 


\section{In Toneguzzo-Norvell, McLachlin J. commented that}

[The plaintiff] is entitled to an award for the loss of earning capacity, not only for the years she will actually live, but for the years she would have lived had she not been injured at birth. It is established that a deduction for personal living expenses must be made from the award for lost earning capacity for the years she will actually live. This is necessary to avoid duplication with the award for cost of future care. The question is whether a similar deduction should be made from the award for lost earning capacity for the years after the plaintiff's projected death. In this case, the bulk of the earnings fall into the latter category.

The trial judge made no deduction for personal expenses. The Court of Appeal deducted 50 per cent on this account. In so ruling, the Court of Appeal followed its earlier decision in Semenoff $v$. Kokan (1991), 59 B.C.L.R. (2d) 195. This approach reflects the view taken in England (Pickett v. British Rail Engineering Lid., [1979] 1 All E.R. 774 (H.L.)) and in Australia (Skelton v. Collins (1966), 115 C.L.R. 94 (H.C.)).

A number of considerations suggest that a deduction for personal living expenses should be made from the award for lost earning capacity during the "lost years". The first is the fact that the projected earnings could not have been earned except on the supposition that the plaintiff would have been alive to earn them. There can be no capacity to earn without a life. The maintenance of that life requires expenditure for personal living expenses. Hence the earnings which the award represents are conditional on personal living expenses having been incurred. It follows that such expenses may appropriately be deducted from the award. Against this, it is argued that if [the plaintiff] had been born a millionaire, her personal living expenses during the "lost years" would have been met from other sources. But this does not negate the fact that in order to earn income one must live and incur the attendant expenses.

I conclude that logical and functional considerations combine to suggest that it is appropriate to make a deduction for personal living expenses from the award for lost earning capacity during the "lost years". 2x

Kerans J.A. accepted the Plaintiff's approach to apply a "lost years" deduction based on the "available surplus" adopted by the U.K. courts in Harris v. Empress Motors Ltd. $^{29}$ and by the British Columbia Court of Appeal in Semenoff v. Kokan. ${ }^{30}$ The Defendant advanced an argument supporting a "lost years" deduction based on the "lost savings" approach. One will note the Court's comment:

I agree that, at first sight, what I spend in a given year is what I would not have spent if I had not been around to spend it. And I agree that a lifetime accumulation of what I did not spend is likely what I will have in my estate at death. I further agree that what I spend on capital items, i.e. what was of enduring value, should, if any value indeed endures until death, also be reflected in my estate.

2* Toneguzzo-Norvell, supra note 26 at $126-28$ [emphasis added].

29 [1983] 3 All E.R. 561 (C.A.).

36) (1991), 84 D.L.R. (4th) 76 (B.C.C.A.) [hereinafter Semenof]. 
The flaw in the "lost savings" approach is that it is heir-centred, not victim-centred. It asks what the heirs lost, not what the victim lost. But the suit here is not for the loss to the estate, it is a suit by the victim for his loss, a claim that by operation of statute survives his death and can be made by his estate for him. Worse, it has the air about it of an attempt to undermine the statute. As a result of this flaw, the approach will fail to take into account what has been called "discretionary" spending, like holidays and entertainment and other "treats". It will also fail to take into account gifts to children and spouses, and thereby underestimate even an heir-centred award.

In my vicw, the law requires that we calculate the expenses that the victim would have incurred in the course of earning the living we predict he would earn. That sum will vary with the kind of employment, and the state in life of the victim. Neither "poverty-line" expenses nor "lost savings" are a reliable indicator of that sum. Rather, it should be a fair calculation of the likely future cost of lives."

Kerans J.A. devoted the bulk of his commentary regarding the "lost years" deduction to the condemnation of the application of the lost savings approach to claims for loss of a chance of earnings. Sulyma J. reiterated this point and provided further detail regarding the appropriateness of the "available surplus" approach, as will be seen in a later section of this article.

In the final result, Kerans J.A. endorsed a 50 percent 1070 percent discount to the deceased's earnings. It is not entirely clear whether or not Kerans J.A. meant that the 50 percent to 70 percent deduction should include or exclude taxes; ${ }^{32} \mathrm{I}$ assume that, given the methodology and case law results, this result does include taxes.

The Court clearly indicated that a "standard of living" benchmark should be used when determining the value of this deduction. In order to assess the deduction suggested by Kerans J.A., Table I-1 provides an historical overview of the case law regarding the magnitude of the "lost years" deduction and the basis for it (i.e. standard of living or otherwise). One will observe from Table I-1 that the courts have used the "standard of living" basis for deductions most often, with an average deduction on that basis of 47.2 percent for a single person with no dependents. Similarly, the average deduction based on "basic necessities" for a single person with no dependents is 46 percent. The average deduction based on "standard of living" for a single person with dependents is 30 percent. ${ }^{33}$ Presumably, the effect of the distinction between "standard

3 Kerans J.A. commented that "[c]ases suggest a discount of $50 \%$ to $70 \%$. My sense of the matter is that this is an apt range. But I suggest that expert evidence could help the judge to assess this cost. The plaintiff actuary here did no calculation. He instead accepted that $50 \%$ of that 'suggested by the cases.' Again, that calculation should include one for tax." (Duncan (C.A.), supra note 4 at 721 [emphasis added]).

33 Analogous information for an average deduction based on "basic necessities" for an individual with dependents is not available from the cases shown in Table 1-1. 
of living" and "basic necessities" is negligible in terms of the deduction applied in the cases.

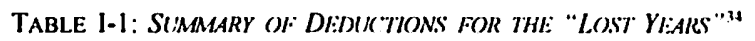

\begin{tabular}{|c|c|c|c|}
\hline Case Citation & $\begin{array}{l}\text { Basis for } \\
\text { Deduction }\end{array}$ & $\begin{array}{l}\% \text { deduction for } \\
\text { single person }\end{array}$ & $\begin{array}{l}\text { \% deduction for } \\
\text { person with } \\
\text { dependents }\end{array}$ \\
\hline $\begin{array}{l}\text { R. v. Jennings (1966), } 57 \text { D.L.R. (2d) } 644 \\
\text { (S.C.C.). }\end{array}$ & N/A & $\mathrm{N} / \mathrm{A}$ & N/A \\
\hline $\begin{array}{l}\text { Andrews v. Grand \& Toy Alberia Lid., [1978] } \\
\text { 2. S.C.R. } 229 .\end{array}$ & $\begin{array}{c}\text { Basic } \\
\text { Necessities }\end{array}$ & $53 \%$ & $N / A$ \\
\hline $\begin{array}{l}\text { Gammell v. Wilson, [1981] } 1 \text { All E.R. } 578 \\
\text { (H.L.). }\end{array}$ & $\begin{array}{l}\text { Standard of } \\
\text { Living }\end{array}$ & $33 \%$ & $25 \%$ \\
\hline $\begin{array}{l}\text { Harris v. Empress Motors Lid., [1983] } 3 \text { All } \\
\text { E.R. } 561 \text { [hereinafter Harris]. }\end{array}$ & $\begin{array}{l}\text { Standard of } \\
\text { Living }\end{array}$ & $50 \%$ & $25 \%-33 \%$ \\
\hline $\begin{array}{l}\text { Bastian v. Mori, [1990] B.C.J. No. } 1324 \\
\text { (B.C.S.C.) (QL). }\end{array}$ & $\begin{array}{c}\text { Basic } \\
\text { Necessities }\end{array}$ & $53 \%$ & $N / A$ \\
\hline $\begin{array}{l}\text { Semenoff v. Kokan (1991), } 59 \text { B.C.L.R. (2d) } \\
195 \text { (B.C.C.A.). }\end{array}$ & $\begin{array}{l}\text { Standard of } \\
\text { Living }\end{array}$ & $N / A$ & $33 \%$ \\
\hline $\begin{array}{l}\text { Duncan v. Kemp, [1991] B.C.J. No. } 1001 \\
\text { (B.C.S.C.) (QL). }\end{array}$ & $\begin{array}{l}\text { Standard of } \\
\text { Living }\end{array}$ & $53 \%$ & N/A \\
\hline $\begin{array}{l}\text { Sigouin v. Wong (1991), (1992) } 10 \text { C.C.L.T. } \\
\text { (2d) } 236 \text { (B.C.S.C.)* }\end{array}$ & $\begin{array}{l}\text { Standard of } \\
\text { Living }\end{array}$ & $33 \%$ & N/A \\
\hline $\begin{array}{l}\text { Dubé v. Penlon (1994), } 21 \text { C.C.L.T. (2d) } 268 \\
\text { (Ont. Gen. Div.). }\end{array}$ & $\begin{array}{c}\text { Basic } \\
\text { Necessities }\end{array}$ & $33 \%$ & $N / A$ \\
\hline $\begin{array}{l}\text { Toneguzzo-Norvell v. Burnaby Hospital, } \\
\text { [1994] I S.C.R. 114. }\end{array}$ & $\begin{array}{l}\text { Standard of } \\
\text { Living }\end{array}$ & $50 \%$ & N/A \\
\hline $\begin{array}{l}\text { Pittman Estate v. Bain (1994), } 112 \text { D.L.R. } \\
\text { (4th) } 257,112 \text { D.L.R. (4th) } 482 \text { (Ont. Gen. } \\
\text { Div.) }\end{array}$ & $\begin{array}{l}\text { Standard of } \\
\text { Living }\end{array}$ & $40 \%$ & $\mathrm{~N} / \mathrm{A}$ \\
\hline $\begin{array}{l}\text { Granger v. Ottawa General Hospital, [1996] } \\
\text { O.J. No. } 2128 \text { (Ont. Gen. Div.) (QL). }\end{array}$ & $\begin{array}{l}\text { Standard of } \\
\text { Living }\end{array}$ & $70 \%$ & N/A \\
\hline $\begin{array}{l}\text { Webster v. Chapman (1997), } 114 \text { Man. R. (2d) } \\
38 \text { (Man. Q.B.).** }\end{array}$ & $\begin{array}{c}\text { Basic } \\
\text { Necessities }\end{array}$ & N/A & $N / A$ \\
\hline $\begin{array}{l}\text { Marchand v. Public General Hospital, [1996] } \\
\text { O.J. No. } 4420 \text { (Ont. Gen. Div.) (QL). }\end{array}$ & $\begin{array}{c}\text { Standard of } \\
\text { Living }\end{array}$ & $50 \%$ & N/A \\
\hline $\begin{array}{l}\text { Brown v. University of Alberra Hospital } \\
\text { (1997), 197 A.R. } 237 \text { (Alta. Q.B.). }\end{array}$ & $\begin{array}{l}\text { Standard of } \\
\text { Living }\end{array}$ & $33 \%$ & $N / A$ \\
\hline $\begin{array}{l}\text { Duncan Estate v. Baddeley (1997), } 196 \text { A.R. } \\
161 \text { (Alta. C.A.). }\end{array}$ & $\begin{array}{l}\text { Standard of } \\
\text { Living }\end{array}$ & $50 \%-70 \%$ & $\mathrm{~N} / \mathrm{A}$ \\
\hline $\begin{array}{l}\text { Duncan Estate v. Baddeley, [1999] A.J. No. } \\
107 \text { (Alta. Q.B.) (QL). }\end{array}$ & $\begin{array}{l}\text { Standard of } \\
\text { Living }\end{array}$ & $\mathrm{N} / \mathrm{A}$ & $35 \%$ \\
\hline
\end{tabular}

- In Sigemin, the deduction was without regard to whether the plaintiff was single or had dependents.

- In Wehiser, Maclnnes $J$. did not make an award during the lost years. 
Although the academic literature on claims of this nature is sparse, some experts advocate a "basic" deduction that does not vary with income level. On this point, we reproduce Kerans J.A.:

In my view, the law requires that we calculate the expenses that the victim would have incurred in the course of earning the living we predict he would earn. That sum will vary with the kind of employment, and the state in life of the victim. Neither "poverty-line" expenses nor "lost-savings" are a reliable indicator of that sum. ${ }^{35}$

\section{b. Income Tax}

In his judgment, Kerans J.A. endorsed the deduction of income taxes from an award for loss of a chance of earnings, as per his comment that

[c]ases suggest a discount of 50 percent to 70 percent. My sense of the matter is that this is apt range. But I suggest that expert evidence could help the judge to assess this cost. The plaintiff actuary here did no calculation. He instead accepted that 50 percent of that "suggested by the cases." Again, that calculation should include one for tax."

This approach is consistent with the deduction of taxes in dependency loss claims pursued under the Fatal Accidents Act, as per Keizer v. Hanna ${ }^{37}$ and Lewis v. Todd, ${ }^{38}$ but is inconsistent with the ruling in $R$. v. Jennings ${ }^{39}$ that damages for loss of earnings in personal injury cases are awarded on the basis of gross (i.e. before-tax) earnings.

\section{c. Contingencies}

The Alberta Court of Appeal's decision in Duncan (C.A.) is relatively silent regarding the application of contingencies to an award for loss of a chance of future earnings, with the Court's only comment being that

[a]dditionally, in this case, there should be a discount for the chance that the victim would not receive the optimal award calculated by the plaintiff's actuary."

As will be shown in the next section, Sulyma J. used this statement to justify the application of a 5 percent contingency (in addition to the 5 percent contingency agreed to ahead of time by counsel) to the loss of a chance of earnings award. It is not entirely clear what the Alberta Court of Appeal meant by this contingency. One possible interpretation would be that the contingency was intended to account for the fact that had he lived, Dean Duncan might not have actually earned the employment income that the Plaintiff's expert based his or her calculation on. However, the likelihood of that occurring is normally addressed via contingencies for earnings growth, mortality, unemployment, or disability as applied to future income estimations; accordingly, 
perhaps the 5 percent contingency in this regard was intended to be an "umbrella" to address the uncertainty in predicting a 16-year-old's lifetime income.

\section{Application of Court of Appeal Methodology by Sulyma J.}

Although the Alberta Court of Appeal provided guidance regarding the calculation of a claim for loss of a chance of future earnings, several matters were left unresolved by its decision, specifically:

- the appropriate methods of calculating the cost of future living expenses;

- the appropriate method to determine income tax; and

- the appropriate discount factors to be deducted from Dean Duncan's preaccident expected earnings over his working lifetime.

Sulyma J. addressed these issues and provided specific guidance regarding the resolution of these concerns when assessing a claim for loss of a chance of future earnings. A summary of the methodologies advocated by the Plaintiff and the Defendant are detailed in Table I-2.

TABLE I-2:

SUMMARY OF APPROACHES ADVOCATED BY THE

PlaintifF AND DEFENDANT IN DUNCAN $(Q . B .)^{41}$

\begin{tabular}{|l|l|}
\hline \multicolumn{1}{|c|}{ Plaintiff's Methodology } & \multicolumn{1}{|c|}{ Defendant's Methodology } \\
\hline $\begin{array}{l}\text { 1. Determine the present lump sum value of the } \\
\text { expected gross income of the deceased over the } \\
\text { working life we predict he would have had but for } \\
\text { the accident; }\end{array}$ & $1 . \quad$ Calculate lost savings, past and future; \\
$\begin{array}{l}\text { 2. Deduct from the gross income calculation the } \\
\text { income tax that would likely have been paid by the } \\
\text { deceased appropriate to the level of predicted } \\
\text { income, in order to determine the present lump sum } \\
\text { value of his expected, after tax income; }\end{array}$ & $\begin{array}{l}\text { 2. Calculate the available surplus by taking into } \\
\text { account the deceased's employment and "state of } \\
\text { life." Determine which items of family } \\
\text { expenditure were not necessarily required to allow } \\
\text { the deceased to maintain and enjoy the standard of } \\
\text { living that we predict he would have earned and } \\
\text { remove those from the predicted total expenditures } \\
\text { of the deceased; }\end{array}$ \\
\hline
\end{tabular}




\begin{tabular}{|c|c|}
\hline Plaintiff's Methodology & Defendant's Methodology \\
\hline & $\begin{array}{l}\text { One arrives at a percentage representing spending } \\
\text { that could be classified as discretionary or } \\
\text { available surplus. It is significant that in items } \\
\text { classified as discretionary or available surplus are } \\
\text { recreation and expenditures such as gifts and } \\
\text { contributions to the family. The applicable } \\
\text { percentage of available surplus is then deducted } \\
\text { from each of the [expenditure] categories past } \\
\text { disposable income [sic]; pre-judgment interest on } \\
\text { the past disposable income; and from the present } \\
\text { value of the future disposable income. The total } \\
\text { that remains in each category is the available } \\
\text { surplus; and }\end{array}$ \\
\hline $\begin{array}{l}\text { 3. Deduct from the estimated "after tax" income } \\
\text { a further amount to reflect the deceased's } \\
\text { expenditures for his personal living expenses over } \\
\text { his pre-accident working life expectancy; and }\end{array}$ & $\begin{array}{l}\text { 3. Calculate the value of capital assets of } \\
\text { enduring value that would have been in existence } \\
\text { at the date it is predicted the deceased would have } \\
\text { died, but for the tortious act. This value ought to } \\
\text { be reduced for contingencies. }\end{array}$ \\
\hline $\begin{array}{l}\text { 4. Deduct a further amount to reflect the } \\
\text { contingencies inherent in predicting the deceased's } \\
\text { life and earnings into the future. }\end{array}$ & \\
\hline
\end{tabular}

The text pertaining to the "Defendant's Methodology" has been transcribed directly from the judgement. A more succinct summary of the Defendant's expert's method is presented below.

The Defendant's expert's approach was to add three components together to calculate the "earning capacity" which would have been left by Dean Duncan's estate after taking into account living expenses during the "lost years" (from the accident to date of death according to life expectancy tables). These consisted of the following:

a) Present value of savings from Mr. Duncan's disposable income, equal to 7.8 percent, less post-retirement expenses, plus

b) Present value of 14.1 percent of Mr. Duncan's disposable income (based on recreation, reading materials, and education expenses), plus

c) Average sale price of a house in Edmonton, deemed to be the only capital asset that would have been acquired and which would have survived Mr. Duncan's death, calculated based on the present value at age 76 . 
Sulyma J. endorsed the Plaintiff's approach to calculating this claim, and emphasized in her ruling that the Defendant's expert neglected to provide the Court with an alternative set of calculations based on the same premises of those of the Plaintiff's expert, or a methodology advocated by the Alberta Court of Appeal in the same case. Unquestionably, the most contentious issue placed before Sulyma J. was the determination of the "lost years" deduction for the case, specifically regarding the quantification of "available surplus" as that term was used in the Court of Appeal's Reasons for Judgment.

\section{a. The Personal Living Expenses Deduction}

The contrasting methodologies provided to the Court diverged on the components of the deduction for personal living expenses. The Plaintiff submitted that future living expenses consist of the deceased's proportionate share of family or shared living expenses, plus the deceased's variable living expenses. The Defendant argued that the Court must assume that the deceased would have provided the necessities of life to his prospective children and these items of expense must also be deducted. Both the Alberta Court of Appeal and Sulyma J. explicitly noted that expenditures on family members are not to be included in a deduction for the deceased's personal living expenses. Specifically, Sulyma J. noted that

[t]here is logic in the defendant's submission that, if we presume Dean Duncan will at some point be married and have children, he will expend money on the necessities of their lives. But such are not within the ordinary meaning of his "personal living expense." Further, there is room for arbitrariness if this deduction is so expanded, by economists or judges, and a danger of improperly eroding the victim's claim.

I found $I$ am bound by the statements of Justice Kerans, who in turn does accept Harris and Semenoff and the relevant quotes that would limit the deduction to Dean Duncan's personal living expenses only, including the following statement of Mr. Justice Kerans at p. 172:

In my view, the law requires that we calculate the expenses that the victim would have incurred in carning the kind of living that we predict he would earn.

And, the principles articulated by $\mathrm{O}^{\prime}$ Connor L.J. in Harris at p. 575:

...(3). Any sums expended to maintain or benefit others do not form part of the victim's living expenses and are not to be deducted from the net carnings.

And further at pp. 575-76:

I think one can say in relation to a man's net earnings that any proportion thereof that he saves or spends exclusively for the maintenance or benefit of others does not form part of his living expenses. Any proportion that he spends exclusively on himself does ... I also reject the "savings" solution because $I$ do not think it is possible to say that 
money spent on others should be reckoned as a part of a man's living expenses in the same sense required by the House of Lords. ${ }^{42}$

In reaching her conclusion on this point, Sulyma J. commented that

I find I must choose one approach in the whole over the other as they were not, after the crossexamination was effected, or otherwise, amenable to being reconciled. Rather, they are mutually exclusive."

\section{This point is again reinforced when the Court remarked that}

I have already rejected the Defendant's approach to calculating this claim. That approach included a deduction for retirement expenses as against a calculation of savings and capital assets at retirement. The Defendant properly pointed out contingencies that ought to be considered in these valuations. For instance, although it was assumed that Dean Duncan would at retirement have a home, it could also be argued that his wife would survive him and therefore that asset ought not to be valued in his estate. It was also argued that he may not have paid off that asset by retirement. If the Defendant's approach were to be valid, these matters would, in my opinion, be properly taken into account by a deduction for contingencies."

Sulyma J. endorsed the Plaintiff's approach as being preferable at law to that of the Defendant, citing Toneguzzo, ${ }^{45}$ Dube v. Penlon, ${ }^{46}$ Brown v. University of Alberta Hospital, $^{47}$ and Granger v. Ottawa General Hospital ${ }^{48}$ as support for the methodology she accepted for the assessment of loss of a chance of future earnings, incorporating a "lost years" factor to arrive at the "available surplus." 49

The court also preferred the Plaintiff's method from a factual standpoint, and commented that personal consumption rates are easier to predict, based on available statistical evidence, than are patterns of savings. ${ }^{50}$ Specifically, personal consumption rates are routinely used to calculate dependency loss awards made pursuant to the Fatal Accidents Act. Personal consumption rates are derived from large expenditure studies, such as the consumer diary data published by the U.S. Bureau of Labor Statistics or Statistics Canada's Family Expenditure Survey (FAMEX), and they essentially represent the living expenses that the deceased would have incurred for his or her exclusive benefit plus the deceased's proportionate share of fixed family expenses. Personal consumption rates are the inverse of dependency rates $^{51}$ used to calculate loss of

Duncan (Q.B.), supra note 4, paras. 36-39 [emphasis added].

Ibid., para. 20.

Ibid., para. 48 [emphasis added].

Toneguzzo-Norvell, supra note 26.

(1994), 21 C.C.L.T. (2d) 268 (Ont. Cl. (Gen. Div.)).

(1997), 197 A.R. 237 (Alta. Q.B.).

[1996] O.J. No. 2129 (Ont. Ct. (Gen. Div.)) (QL).

Duncan (C.A.), supra note 4, para. 28.

Ibid., para. 30.

"Dependency rates" are the inverse of personal consumption rates and represent that portion of the deceased's income that he or she would have spent for the benefit of his or her dependents. For example, if the deceased in a four-person family had a 21 percent personal consumption rate (i.e. he or she spent 21 percent of his or her disposable income on personal expenses), then the 
dependency awards, and conceptually, personal consumption rates are the same as personal living expenses, or the "lost years" deduction.

For example, in Gehrmann v. Lavoie, ${ }^{52}$ a fatal accident action, the Supreme Court of Canada held that it was wrong to charge the deceased's statutory beneficiaries with the full cost of the family car; rather, what should have been attributed to the deceased was the marginal value of the car to him, thus leaving the remaining value as part of the family dependency.

In the same vein, in Duncan (C.A.), Kerans J.A. and Sulyma J. noted that the "lost years" deduction accounted for those expenditures that the deceased would have spent on himself in earning the type of living that he would have pursued, plus his proportionate share of the family's living expenses; expenditures made by the deceased for the benefit of others (i.e. family obligations) were not to be included in the "lost years" deduction.

Table I-3 below details the results of a survey of personal expenditure rates from various sources, for families of varying size.

TABLE I-3:

Personal Consumption rates to allocate to the Deceased, Depending on family Size

\begin{tabular}{lccccc}
\multicolumn{1}{c}{ Source } & $\begin{array}{c}2 \text {-adult } \\
\text { family }\end{array}$ & $\begin{array}{c}2 \text {-adults, } \\
\text { 1 child }\end{array}$ & $\begin{array}{c}2 \text { adults, } \\
\text { 2 children }\end{array}$ & $\begin{array}{c}2 \text { adults, } \\
3 \text { children }\end{array}$ & $\begin{array}{c}2 \text { adults, } \\
4 \text { children }\end{array}$ \\
\hline Cheit $(1961)^{51}$ & $30.0 \%$ & $26.0 \%$ & $22.0 \%$ & $20.0 \%$ & $18.0 \%$ \\
King and Smith (1988) & $23.4 \%$ & $21.7 \%$ & $17.7 \%$ & $16.4 \%$ & $13.7 \%$ \\
Bruce (1992) & $30.0 \%$ & N/A & $17-24 \%$ & N/A & $15.0 \%$ \\
$\begin{array}{l}\text { Department of Labor (U.S.) } \\
(1994)^{s 6}\end{array}$ & $40.0 \%$ & $30.5 \%$ & $24.0 \%$ & $17.2 \%$ & $11.4 \%$
\end{tabular}

$(1994)^{\text {s6 }}$

surviving family's dependency rate would be 79 percent (meaning that the deceased spent 79 percent of his or her disposable income on goods and services to benefit his or her dependents). For a comprehensive discussion of personal consumption rates and dependency rates, see $W$ rongful Death Claims, supra note 25.

$52 \quad$ (1975), 59 D.L.R. (3d) 634 (S.C.C.).

53 E.F. Cheit, Injury and Recovery in the Course of Employment (New York: John Wiley \& Sons, Inc., 1961).

s4 These results are specific to the age of the family head (i.e., between 35 and 54). It should be noted that King and Smith's (E.M. King \& J.P. Smith, Computing Economic Loss in Cases of Wrongful Death (United States: Rand Institute for Civil Justice, 1998)) results are actually an average of three methodologies by M. Orshansky, Table 11 in B.S. Mahoncy, ed., The Measure of Poverty (Washington, D.C.: U.S. Department of Health, Education, and Welfare, 1976); E.P. Lazear \& R.T. Michacl, Allocation of Income Within the Household (Chicago, University of Chicago Press, 1988), and the Bureau of Labor Statistics, Revised Equivalence Scale for Estimating Equivalent Incomes or Budget Costs of Family Types, Bulletin no. 1570-2 (Washington, D.C.: U.S. Department of Labor, 1968).

ss These percentages are calculated by estimating the residual from the dependency rates shown in Table 11.8 of C.J. Bruce, Assessment of Personal Injury Damages, $2 \mathrm{~d}$ ed. (Toronto: Butterworths, 1992).

\$6 U.S. Bureau of Labor Statistics, Consumer Expenditure Survey (Washington, D.C.: U.S. Department of Labor, 1994) [hereinafter Consumer Fxpenditure Survey]. 


\begin{tabular}{cccccc} 
Source & $\begin{array}{c}2 \text {-adult } \\
\text { family }\end{array}$ & $\begin{array}{c}2 \text {-adults, } \\
1 \text { child }\end{array}$ & $\begin{array}{c}2 \text { adults, } \\
2 \text { children }\end{array}$ & $\begin{array}{c}2 \text { adults, } \\
3 \text { children }\end{array}$ & $\begin{array}{c}2 \text { adults, } \\
4 \text { children }\end{array}$ \\
\hline Martin $(1994)^{57}$ & $31.0 \%$ & $23.9 \%$ & $20.1 \%$ & $15.1 \%$ & $12.4 \%$ \\
Brown $(1999)^{58}$ & $32.9 \%$ & $21.0 \% \%^{59}$ & $17.8 \%$ & $13.8 \%^{(1)}$ & N/A \\
\hline AVERAGE & $31.22 \%$ & $24.62 \%^{61}$ & $20.35 \%$ & $16.5 \%^{62}$ & $14.1 \% \%^{6.3}$
\end{tabular}

Accordingly, Sulyma J. found the Plaintiff's approach to be less speculative than that of the Defendant, and noted that application of the lost savings approach advocated by the Defendant would unnecessarily compound speculation, especially in the face of the speculative exercise of valuing lost earnings for a person not yet earning an income. ${ }^{64}$ The Court also cited the Plaintiff's calculation of lost income after contemplating personal expenditures as being preferable from a factual standpoint. ${ }^{65}$

Sulyma J. found support for her conclusion in the Plaintiff's reliance on Harris v. Empress Motors, ${ }^{66}$ wherein O'Connor L.J. enunciated three principles, for a unanimous Court of Appeal, regarding the "available surplus" approach:

1. The ingredients that go to make up "living expenses" are the same whether the victim be young or old, single or married, with or without dependents;

2. The sum to be deducted as living expenses is the proportion of the victim's net earnings that he spends to maintain himself at the standard of life appropriate to his case;

3. Any sums expended to maintain or benefit others do not form part of the victim's living expenses and are not to be deducted from the net earnings.

G.D. Martin, Determining Economic Damages (Santa Ana, California: Jarnes Publishing Inc., 1994, combined the following various U.S. studies to arrive at these estimates: Bureau of Labor Statistics bulletins, research by the Rand Institute, the Urban Institute, and numerous other forensic economists in the U.S.

Statistics Canada, Family Expenditure in Canada, 1996, Catalogue 62-555-XPB (Ottawa: Statistics Canada, 1996), Table 11 and Statistics Canada, Family Expenditure in Canada, 1996, IPS 62F0019 (Ottawa: Statistics Canada, 1999), Table 9 [hereinafter Family Expenditure in Canada, 1996]. These tables were customized compilations prepared by Statistics Canada for Brown Economic Assessments Inc.

This percentage was derived from Statistics Canada, Family Expenditure in Canada. 1992, Catalogue 62-555 (Ottawa: Statistics Canada, 1992), Table 17 [hereinafter Family Expenditure in Canada, 1992] rather than Family Expenditure in Canada. 1996, supra note 58, Table 11; the latter did not allow us to make such a derivation. This percentage is relatively lower than the other estimates in the same category because it consists of two adults and three or more children.

We have not included the Bruce figures in this average due to the omitted estimates for 2 adults and 1 child families.

We have not included the Bruce figures in this average duc to the omitted estimates for 2 adults and 3 children families.

Due to the omitted estimates for 2 adults and 4 children families from Statistics Canada, Family Expenditure in Canada, 1996, we have not included the Brown ligures in this average. 
Sulyma J. also endorsed the Plaintiff's reliance on The Quantum of Damages by Kemp and Kemp, ${ }^{67}$ citing that

[t]he basic principle is that sums spent to maintain the victim at the standard of life appropriate to his case should be deducted. This is subject to the qualification that sums expended for the joint benefit of the victim and others should only be regarded as the victim's living expenses to the extent of his share of the joint expenditure.

\section{Married man with no children}

Take the case of a married man with no children and apply the conventional basis of calculating the dependency, described by O'Connor L.J. The Fatal Accidents Act dependency would be about 66 per cent, of net earnings, including therein about 33 per cent for joint expenditure. Deduct half the value of the joint expenditure, and the resulting deduction is about 50 per cent.

But in making such an assessment in the case of a young, newly married victim, it would not be right to assume that this childless state would necessarily continue (per O'Connor L.J. in the Harris case [1984] I W.L.R. at p. 231 A). Accordingly, after the expiry of part of the lost years, it might be right to assess his deductible living expenses on the basis of a married man with, say, two children. On the other hand a middle-aged couple, who have been married some time and have no children, may reasonably be deemed to remain childless. Much depend [sic] on the facts of the particular case.

\section{Married man with wo children}

On the same conventional basis take the case of a married man with two children. The Fatal Accidents Act dependency would be about 75 per cent. of net earnings. The items of joint expenditure, namely, rent or mortgage interest, rates, heating, gas, electricity, motor car, TV etc., would not significantly increase with the increased family unit, and so would remain at about 33 per cent. of net earnings. One quarter of this joint expenditure is to be added to living expenses solely attributable to the victim, say, 8 per cent. The resulting deduction for living expenses would be 25 per cent, plus 8 per cent, i.e. 33 per cent. ${ }^{6 . *}$

In more precise figures, the Kemp example of a 75 percent dependency rate for the surviving family of a deceased married man with two children leads to a 6.25 percent deduction for joint fixed expenditures, (i.e. 36.25 percent $=(100$ percent -75 percent $)$ $+[(100$ percent -75 percent $) / 4])$, we do not accept these percentages outright; rather, we use the Kemp methodology to derive the deduction, but substitute Canadian data for that of the U.K. (see Section II.E, below).

Finally, Sulyma J. commented on the Plaintiff's use of Semenoff v. Kokan ${ }^{69}$ to support the Court's methodology, noting the comments of Hutcheon J.A., for a unanimous Court of Appeal that 
Gordon Semenoff married Valerie Semenoff about two months before the tragedy. There are no children of the marriage, but we are asked to assume that there would have been at least two children. It would not be right to assume the childless state would have continued and the assumption we are asked to make appears reasonable.

[Plaintiff's counsel] has submitted that the defendant, with the burden of proof on him, has produced no evidence to support a deduction. We know, however, that in this hypothetical calculation living expenses must be present. In the absence of precise figures, I think that we are justified in accepting the conventional deduction of 33 percent discussed in Harris.

One will note that the Alberta Court of Appeal also referred to Semenoff and Harris in Duncan (C.A.).

Sulyma J. determined that the Plaintiff's methodology was most consistent with the directions of the Alberta Court of Appeal, with the purpose of the award, and with the principles of awards in this area of the law. The court noted that the purpose of the award is to compensate the deceased for his lost earnings (not lost savings), and reiterated that Kerans J.A. noted in his judgment that lost savings are not the correct method of assessment for claims of this nature. ${ }^{70}$

Sulyma J. specifically rejected "basic necessities" as the basis for the deduction for personal living expenses. The Court instead endorsed the use of the "standard of living" benchmark for estimating personal living expenses, which is consistent with the majority of the case law reviewed in Table I-1 and the direction of Kerans J.A. that

it was said for the appellant [plaintiff] that I am bound to seek out only what would have been the cost of "basic necessities" had the victim lived. My impression was that what was sought was some sort of poverty-line calculation - the amount required to spend to avoid starvation and remain sufficiently healthy to work. It was suggested that this was the approach for calculation of living expenses taken by the Supreme Court of Canada in Andrews v. Grand and Toy. I do not agree. The decision in that case spoke of the need to deduct either from future care or from projected earnings the "types of expenses that would have been incurred in any event" (p. 251) and referred to these as "basic necessities". But in the context I think Chicf Justice Dickson used the phrase "basic necessities" merely to emphasize the ordinariness of those expenses, as compared to the extremely high expenses associated with future care of a victim who has been rendered a quadriplegic."

b. Personal Expenses Accepted in Duncan v. Baddeley

In order to earn income one must live and incur expenses to do so. Personal expenses, as described by the Alberta Court of Appeal and in other decisions rendered by various courts, include:

- earnings not spent (e.g. savings); 
- capital items of enduring value; and

- "discretionary" spending on items such as holidays, entertainment, and other "treats."

Personal expenses will vary with the kind of employment and the state in life of the victim, and they comprise a "fair calculation of the likely future cost of lives."

Personal expenses should not be confused with poverty-line expenses. Rejecting poverty-line expenses as personal expenses is in accordance with the principle that expenses vary with the kind of employment and the state in life of the victim; otherwise, awards would not fluctuate in line with the deceased's income, but rather increase as the deceased's income increased (and would become very large for victims with high incomes).

Personal expenses do not just represent "lost savings." Rejecting "lost savings" as personal expenses appears to be in accordance with a "victim-centered" approach, which the Alberta Court of Appeal argued is meant by the estate's claim - it is a suit by the victim for his loss and is not intended to represent what remains in the estate for the deceased's beneficiaries (i.e. savings or capital items).

In a similar vein, personal expenses do not include gifts to spouses and children this also flows from a "victim-centered" approach, which is contrary to the principles underlying Fatal Accidents Act claims which are "heir-centred" (the Fatal Accidents Act empowers the deceased's dependents to assess their loss of dependency).

Personal expenses have two primary components:

1. The deceased's share of his or her own variable expenses and divisible shared expenses, spent to maintain his or her standard of living, which fluctuates according to income level (hence the method of using percentage of income); and

2. The deceased's share of indivisible (fixed) shared expenses, spent to maintain his or her standard of living, which fluctuates according to income level.

The first component of personal expenses is exactly similar to the inverse of dependency rates used in Fatal Accidents Act claims, called "personal consumption rates," (see Table I-3 above) e.g. a 70 percent dependency rate would result in a 30 percent personal consumption rate.

The second component of personal expenses is added on to capture the deceased's share of fixed (capital) items that he or she consumes or enjoys to maintain his or her standard of living (e.g. shelter, furnishings, transportation). These amounts are not attributed to decedents in Fatal Accidents Act cases because, in such situations, it is the dependents who must maintain their pre-accident standard of living, and precisely because these items are indivisible (due to the nature of the capital items), 100 percent of these items are required by dependents. In Survival of Actions Act cases, this additional component is attributed back to the deceased (instead of to the dependents 
as in Fatal Accidents Act cases) because the Survival of Actions Act principles dictate a "victim-centred," rather than an "heir-centred," approach. The result of this is that there is a higher deduction attributable to the deceased in Survival of Actions Act cases than in Fatal Accidents Act cases (although this can vary depending on the relativity of the adult survivor and adult deceased incomes). ${ }^{72}$

The personal expenses ("lost years") deduction therefore results in an award which encompasses:

- The deceased's savings;

- The deceased's enduring capital items;

- The share of the deceased's income spent on family members (or other dependents, such as parents); and

- The "luxury" or "discretionary" component of the deceased's expenditures.

The unique aspect of the award is that it is comprised of:

- $\quad$ income earned and not spent (i.e. saved);

- income that is transformed into other goods (e.g. capital items);

- income that is spent on others (e.g. family members); and

- income that is spent on items or events that are not critical to "earn the income one needs to live" (luxury or discretionary items) or the "likely cost of a life."

These items appear to constitute the "available surplus."

Sulyma J. ultimately accepted the Plaintiff's submission regarding the theory behind and magnitude of the "lost years" deduction, and remarked that

I accept the Plaintiff's expert, Ms. Brown's deduction of 35 percent from net earnings for personal living expenses. Mr. Smith did not do a calculation of the value of personal living expenses on the appropriate basis and I therefore only have Ms. Brown's evidence on this issue."

The reader should note that the 35 percent deduction for personal living expenses proposed by the Plaintiff and endorsed by the Court was based on the presumption that Dean Duncan would have married and had two children. ${ }^{74}$ Had the calculation been done on the basis of Mr. Duncan remaining single with no dependents through his life,

See Table 5 regarding the relativity of the survivor's and deceased's income in Brown, supra note I at 1125 .

7 Duncan (Q.B.), supra note 4, para. 42.

7 See Section II, subsection E, below, for statistics regarding marital status/age of marriage, and family size. 
I suspect a "lost years" deduction of 50 percent would have been advocated, ${ }^{75}$ although this could vary accordingly in other cases with specific evidence about the deceased. As will be explored later in greater detail, economies of scale dictate that several people can live more cheaply, on a per person basis, than an individual; accordingly, a (deceased) member of a large household will have a smaller deduction for personal living expenses than a single person or a member of a smaller household. This arises from the Duncan (Q.B.) finding that support for family members forms part of the estate claim, not the deduction for personal living expenses; and it is in accordance with personal consumption rates in dependency cases litigated under the Fatal Accidents Act.

It was assumed that Dean Duncan would have married at age $28{ }^{76}$ Statistics show that the majority of Canadian families have children; specifically, of the 717,000 families in Alberta in 1995, 36 percent of those were couples without children. Of the couples who had children, 51 percent had two parents, whereas 13 percent were loneparent families. ${ }^{77}$ On a national level, of the 7,904,000 families in Canada in 1995, 37 percent of those were couples without children, 50 percent were couples with children, and 13 percent were lone-parent families. ${ }^{78}$ See Section I.E. for additional statistics on marriage and cohabitation rates, age at first marriage, fertility rates, and timing of child-rearing.

One will note that Sulyma J. did not rigourously apply the correlation between family size and the magnitude of the deduction for personal expenses, to the extent that a 35 percent deduction was applied across Dean Duncan's projected life span even though the children would not have been present in the household for the deceased's entire life span. It is my belief that Sulyma J. did not make an adjustment for this because other (positive) adjustments had also been ignored - for instance, that Mr. Duncan may have had more than two children and that he may have accumulated an estate which would have been bequeathed upon his death. ${ }^{79}$ In any event, we have compiled statistics that allow us to make adjustments for varying family size over the life cycle - these are detailed in Section II.E., below.

\section{c. Income Tax}

As indicated above, Sulyma J. endorsed the Plaintiff's approach to assessing the quantum of the Duncan v. Baddeley claim. Included in that approach was the deduction of income taxes from the award:

The Plaintiff's method of determining the effect of income tax was to deduct an expected tax [rate] of

28 percent from calculated gross carnings on a present value basis. She employed 1998 tax brackets

7s Brown, supra note 1.

7. As per statistics provided in Vanier Institute of the Family, From the Kitchen Table to the Boardroom Table (Nepean: Vanier Institute of the Family, 1998) Table III.

$n$ As per statistics provided in ibid, Table I, and Statistics Canada, Annual Demographic Statistics, Catalogue 91-213-XPB (Ottawa: Statistics Canada, 1995).

$7 \times \quad$ Ibid.

7" No award was made for the accumulated assets that would have been left to the estate after Dean Duncan would have retired or died in the absence of the accident in question. 
and credits and did not employ any "de-indexing factor" in her calculation of expected income tax in respect of post-trial income.

The Defendant submits that this case significantly altered the law in relation to the impact that tax can and will have on the calculation of future damages not only in survival actions but also in personal injury actions where future loss of income or earning capacity is claimed. ...

In my view the Court of Appeal did not intend to and did not change the conventional compensation for future loss of income in all personal injury cases. Rather, the Court was distinguishing a claim such as this one, where "lost years" are in issuc and compensation is net of saved expenses and including tax as a certain expense. I find no fault with the Plaintiffs method of taking tax off gross income and then applying the living expenses deductions to that amount."

Sulyma J. determined that the risk of de-indexation of income taxes should be dealt with as a contingency, noting the Plaintiff's argument that the Defendant's expert's assumption of a constant factor for the de-indexing of income tax would require the Court to make assumptions regarding future inflation rates and the manner in which the government would react to future inflation rates. ${ }^{81}$ Sulyma J.'s ruling in this regard is consistent with Cooper-Stephenson, which reads:

Future Tax Policy

It seems fairly well accepted that the calculations should by and large be predicated on the basis of current tax policy, since potential alterations in tax rates up or down will be a matter of speculation and, in any event, over a lengthy period of time might cancel each other out. An issue remains, however, as to the relationship of tax brackets to inflation. McEachern C.J.B.C. in Scarff v. Wilson had suggested that the "tax structure at the time of the award, adjusted for any proven long-range taxation trends and discounted for reasonable tax saving devices, if any, is a usable model." In light of this, Finch J. in Tucker (Guardian ad litem of) v. Asleson preferred the current tax policy of assuming "an annual index creep of 2 percent," rather than, as the defendants had contended - and which seems a fairer assumption - that tax brackets would keep pace with the actual rate of inflation over the long term. The Ontario Law Reform Commission suggested that, "given that the ratio of aggregate income taxes to aggregate personal income has remained virtually unchanged since 1970 , it is reasonable to assume that the nominal amounts in the tax system, such as the personal exemption and the tax brackets, will be increased with inflation," and it therefore proposed that "all fixed dollar amounts in the Income Tax Act should be assumed to increase annually at the assumed rate of inflation ..." As a matter of practice, the courts often include the possibility of changes in tax policy as a consideration in a global reduction of the gross-up figure based on a general uncertainty with respect to the future. ${ }^{\mathrm{N}}$

Duncan (Q.B.), supra note 4, paras. $43-45$ [emphasis added].

*I Ibid., paras. 46-47.

x2 K. Cooper-Stephenson, Personal Injury Damages in Canada, 2d ed. (Toronto: Carswell, 1996) at 476-77 [emphasis added]. 


\section{d. Contingencies}

In addition to the 5 percent contingency reduction agreed to by the parties to the action, Sulyma J. applied Kerans J.A.'s remark that a contingency should be applied to the award to account for the chance that the victim would not receive the optimal award calculated by the Plaintiff's actuary to justify an additional 5 percent contingency deduction from the award. ${ }^{83}$ Sulyma J. supported her conclusion on the proposition that

[i]n my opinion, this discount would most likely by applied to the portion of the actuary's calculations that are premised on predictions of the deceased's future education and thereafter employment and income. This type of evidence is necessarily speculative where the deceased is an infant or is youthful. However, I am not faced with such speculative evidence in this case as the parties reached an agreement on income.

I find it probable that Dean Duncan's living expenses could have varied from the statistical average. As was pointed out by Justice Kerans, living expenses will vary with the kind of employment and the state in life of the victim. The parties had agreed to an income amount on which 10 calculate gross earnings but did not lead evidence that would assist in determining what kind of employment would lead to that income. As expenses can vary with many kinds of employment which could achieve the annual income attributed to Dean Duncan, I discount the award of $\$ 447,687.50$ by an additional 5 percent to reflect this contingency and to reflect the comment of Justice Kerans that there should be a discount for the chance that the victim would not receive the optimal award calculated by the Plaintiff's actuary. The contingency of the risk in assuming a constant factor as a tax deduction is also accounted for in this percentage and in the contingency deduction percentage agreed upon by the parties. $^{\text {"4 }}$

Based on the rationale provided by Sulyma $J$. for this additional 5 percent contingency, one can question whether this deduction would be applicable in all claims for loss of a chance of future earnings. The Court's comments were very fact-specific, and it is arguable that in a case where the court is provided with specific evidence regarding the type of employment that the deceased would have pursued but for the accident, this additional 5 percent contingency deduction may in fact be increased or decreased. For example, if the court had been presented with evidence that the deceased planned to be a commissioned salesperson, it may have increased the additional 5 percent deduction to account for occupation-specific expenses such as specialized work equipment, clothing, and transportation costs to and from remote locations, all of which may not be provided by the deceased's employer. Conversely, if evidence established that the deceased would have been a sedentary white-collar worker, the court may have endorsed a lower contingency deduction than the additional 5 percent, based on the assumption that the deceased would have incurred lower costs in pursuing his employment rather than that of an alternative type of worker. 


\section{e. Calculations}

The formula that Sulyma J. used to calculate the claim for loss of a chance of earnings essentially involved the application of the "lost years" deduction to Mr. Duncan's net income, the subsequent application of the contingency deduction agreed upon between the parties to the resulting amount, and the further reduction of that second amount by a Court-imposed contingency deduction. Put another way, the formula that was used to determine the final award for loss of a chance of earnings was:

Award for loss of a chance of future earnings $=\{[y \times(1-a)] \times[1-b] \times[1-c] \times[1-d]\}$

Where

$y=$ present value of deceased's gross income, including all pre-trial income

$a=$ percent deduction for income taxes

$b=$ percent deduction for personal living expenses (i.e. "lost years" \% deduction)

$c=$ percent deduction agreed upon by parties to action

$d=$ additional percent deduction imposed by the Court

Sulyma J. used the following amounts to arrive at an award in Duncan (Q.B.) for loss of a chance of earnings:

- Present value of Dean Duncan's gross income, had he lived $=\$ 1,006,500^{85}$

- Deduction for income tax against Dean Duncan's gross earnings $=28$ percent

- Deduction for personal living expenses (i.e. "lost years" deduction) $=35$ percent

- $\quad$ Contingency deduction agreed upon by parties $=5$ percent

- Additional contingency deduction endorsed by Sulyma J. $=5$ percent

Accordingly, Sulyma J. applied the above formula the following way: 
final award for loss of a chance of earnings, not including prejudgment interest

$=\{[\mathrm{y} \times(1-\mathrm{a})] \times[1-\mathrm{b}] \times[1-\mathrm{c}] \times[1-\mathrm{d}]\}$

$=\{[\$ 1,006,500 \times(1-0.28)] \times[1-0.35] \times[1-0.05] \times[1-0.05]\}$

$=\{[\$ 1,006,500 \times 0.72] \times 0.65 \times 0.95 \times 0.95$

$=\{\$ 724,680 \times 0.65 \times 0.95 \times 0.95\}$

$=\$ 425,115^{86}$

As of the time of writing this article, there has been no subsequent application of this formula in the case law; one should note, however, that there has been no subsequent treatment of Duncan v. Baddeley in Alberta since Sulyma J.'s decision was rendered in early 1999. Accordingly, the above formula represents a court-endorsed methodology for calculating a claim for loss of a chance of earnings pursued under the Survival of Actions Act and based on Duncan v. Baddeley.

\section{Duncan v. Baddeley - Treatment in SubSequent CaSe LaW}

The Alberta Court of Appeal's decision in Duncan (C.A.) has been given notice in the recent decisions of Lamey v. Wentworth Valley Developments Ltd. ${ }^{87}$ Woollard v. Coles, ${ }^{88}$ Throness Estate v. Kerr, ${ }^{89}$ Schiewe v. Skogan, ${ }^{90}$ and Brooks v. Stefura. ${ }^{91}$ One will note, however, that criticism directed toward the Duncan (C.A.) decision has questioned the policy implications of it, rather than the methodology endorsed by it.

The chambers judge in Lamey ${ }^{92}$ strongly criticized the decision in Duncan (C.A.). At issue in that case was whether Nova Scotia's Survival of Actions Act $^{93}$ permitted a deceased person's estate to claim damages from a tortfeasor for the loss of a chance of future earnings. The court in Lamey distinguished Duncan (C.A.) on the basis that s. 3 of the Nova Scotia Survival of Actions Act, provides that "only damages that have resulted in actual pecuniary loss to the estate are recoverable," 94 whereas s. 5 of Alberta's Survival of Actions Act provides that "only those damages that resulted in actual financial loss to the deceased or his estate are recoverable." 95 On 14 April 1999, the Nova Scotia Court of Appeal ruled on a procedural note in this matter and held that the chambers judge erred in barring an amendment to the plaintiff's pleadings to claim loss of a chance of future earnings. Accordingly, it remains to be seen whether claims of this nature will be permitted in Nova Scotia. 
In Ordon Estate v. Grail, ${ }^{96}$ the Supreme Court of Canada ruled that the survival of actions should be permitted in the context of Canadian maritime law. ${ }^{97}$ In that case, the lawsuits at bar arose from four negligence actions relating to two boating accidents that occurred in Ontario. lacobucci and Major JJ. remarked, for the Court:

[W]e would permit an executor or administrator to bring a claim in the deceased's name for negligence to the person of the deceased in the same manner and with the same rights as the deceased would have been entilled to do, had he or she lived.... In so permitting an executor or administrator to bring such a claim, we would also include within this change in the common law the related principles and procedures that are necessarily implied by or connected with executors' or administrators' claims for the proper enforcement of such claims."

The Court justified the inclusion of the survival of actions in maritime law on the basis that every common law jurisdiction in Canada has passed a law permitting recovery by the estates of deceased persons. Put another way, it appears that the Court was attempting in its ruling to bring maritime law "into conformity with the general practice in all other jurisdictions within this country." 99 One should note that the Court also provided a four-pronged test to determine the applicability of a provincial statute in the context of maritime law. The relevance of this point is that this test may provide a future method to determine the applicability of a provincial statute permitting a Duncan v. Baddeley type claim to a maritime law action, given that maritime law is silent regarding the specific acceptability of claims for loss of a chance of earnings.

In Woollard v. Coles, ${ }^{100}$ the Manitoba Court of Queen's Bench used the Duncan (C.A.) decision to help support an award for general damages for a plaintiff's estate. In that case, the defendant argued that general damages representing compensation for non-pecuniary losses such as loss of amenities, pain and suffering, and loss of expectation of life, were no longer pertinent to a deceased. Duval J. used the decision in Duncan (C.A.) to justify the survival of a deceased plaintiff's non-pecuniary claim for the benefit of his estate.

In Throness Estate v. Kerr, ${ }^{101}$ the Duncan decision was material because the point at issue was whether the applicable law in the case at bar was British Columbia law which expressly prohibits Duncan v. Baddeley type claims under the Estate Administration Act of British Columbia, s. 66(2), or Alberta law, which allows claims of this type, as per the Alberta Court of Appeal's decision in Duncan v. Baddeley. In Throness, Kent $\mathrm{J}$. determined that unless the plaintiff was able to prove that any

Ordon Estate v. Grail, [1998] 3 S.C.R. 437 [hereinafter Ordon].

Maritime law is described in Ordon as a comprehensive body of federal law that addresses all claims in respect of maritime and admiralty matters - it is mandatory throughout Canada and is not the law of any single province. In the context of a collision between boats (as in Ordon) or some other accident, maritime negligence law encompasses the range of possible claimants, the scope of available damages, and the availability of a regime of apportionment of liability according to fault.

Ordon, supra note 96 at $516 \cdot 17$ [emphasis added].

Ibid. at 516.

Woollard, supra note 88.

Throness, supra note 89. 
possible part of the wrongful act occurred outside of British Columbia, then the applicable law was that of British Columbia. ${ }^{102}$

Schiewe v. Skogan ${ }^{103}$ recently provided the Alberta Court of Appeal with an opportunity to comment that "[i]t is now established that a claim for loss of future earnings survives the death of the victim regardless of whether there is a concurrent claim for loss of dependency." 104 The Court in Schiewe noted that the interdependency of Fatal Aecidents Act claims and Survival of Actions Act claims, when advanced concurrently, necessitate that the awards for loss of dependency and loss of a chance of earnings be considered together. In the result, the Court returned the case to the trial judge to hear and assess the quantum issue, but Reasons for Judgment were not available at the time of writing regarding the re-assessment of the award for loss of a chance of future earnings in Schiewe.

\section{E. DUNCAN V. BADDELEY - ASSUMPTIONS REgaRding Marital Status and Size of Family ${ }^{105}$}

As indicated above in Section II.C.2.a. ("The Personal Living Expenses Deduction"), the 35 percent "lost years" deduction that Sulyma J. endorsed was based on the assumption that Dean Duncan would have married and had two children. This section provides statistics to support that assumption, ${ }^{106}$ but also looks at adjustments for varying family sizes over the life cycle.

\section{Probability of Marrying/Age at First Marriage}

Statistics Canada classifies people as never married, married, widowed, and divorced. The married category includes individuals who are married and living with their spouse, those who are legally married but separated, and those who are cohabiting, regardless of marital status. The percentage of married men peaked in 1971 and for women in 1961. The proportion of legally married adults has declined since those years and is currently at its lowest rates in the post-war period. ${ }^{107}$

The grouping together of legally married couples with cohabiting couples in some sources leads to the conclusion that the change in the total number of married Canadians is more significant than the change in the percentage married because of the increase in cohabitation among those aged 15 to 29 . The percentage of married adults (both male and female aged 15 to 29) has decreased over the last ten years, attesting

\section{2}

103

I14

Ios

$I(x)$

Ibid, para. 8.

Schiewe, supra note 90.

Ibid, para. 12.

To obtain more detailed statistical data regarding family size, probability of marrying, and age at first marriage, please contact the author.

Any probabilty that the deceased would have divorced and/or remarried would properly be addressed as a divorce/remarriage contingency as applied to the deceased's before-tax carnings. For a discussion of the application of remarriage contingencies in wrongful death assessments, see Wrongful Death Claims, supra note 25.

Statistics Canada, Family Over the Life Course: Current Demographic Analysis, Catalogue 91543E (Ottawa: Statistics Canada, 1995), Table A1.1 [hereinafter Family over the Life Course]. 
to a declining trend from 1971. However, the total percentage of persons cohabiting has increased over the last ten years. This trend is especially prevalent among those aged 25 to 29; the percentage cohabiting increased from 8 percent to 14 percent for men and from 7 percent to 14 percent for women between 1981 and $1991 .^{108}$

Also worth noting, martial status varies with educational attainment. Between 1971 and 1991, those with post secondary (non-university) education: had the highest marriage rate and those with a secondary school education had the lowest marriage rate. People with a high school education are the most likely to be in a cohabiting relationship. Those with university education are the least likely to be in a cohabiting relationship. ${ }^{109}$

Data regarding the historical marital status for adults aged 30 to 54 from 1921 to 1991 shows that the marriage rate in this age group was increasing each decade until 1971 and has been declining since 1971. The divorce rate has increased since 1971 at a rate of increase of eight times for men and five times for women. ${ }^{10}$

In 1991, 56 percent of men and 54 percent of women aged 30 to 55 were living at home with their spouse and their children, the most common living arrangement in Canada for persons aged 30 to 55, although they are lower than the 1981 figures. Almost 82 percent of men and 79 percent of women lived with someone else (spouse, child, or parent) in 1981; these percentages declined to 79 percent and 75 percent, respectively, in 1991."'

The average age at first marriage for men and women has continually increased since 1961. Specifically, in 1961, men were marrying at an average age of 25 and in 1995 they were marrying at an average age of 28 ; in 1961, women were marrying at an average age of 22 , and, in 1995 , the average age of marriage for women was $266^{112}$ Based on the above statistics and the increasing trend since 1961, we assume that if the deceased was under 30 , that he or she would have married at age 28 or 26 , respectively.

\section{Probability of Having Children/Family Size}

The total fertility rate refers to the average number of children a woman can expect to have in her lifetime, based on the fertility rates of a given year. It is equal to the sum of age-specific fertility rates (ages 15 to 49 ). The total fertility rate in Canada reached a post World War II low in 1987, when the total fertility rate was 1.57 . However, in the 1990s the total fertility rate has remained constant at a rate of 1.70 children borne

Ibid., Table 1.1.

Ibid., Table Al.2. Categories of highest Icvel of educational attainment achieved included elementary school, secondary school, post-secondary school (non-university), and post-secondary school (university).

Family Over the Life Course, supra note 107, Table 2.1.

Ibid., Table 2.5.

Data for 1961, 1981, and 1995 were obtained from Statistics Canada, Marriage and Conjugal Life in Canada: Current Demographic Analysis, Catalogue 91-534 (Ottawa: Statistics Canada, 1978). Data for 1971 to 1990 were obtained from Statistics Canada, A Portrait of Families in Canada, Catalogue 89-523E (Ottawa: Statistics Canada, 1993), Table 1.7. 
by women in the reproductive years, and the rate is projected to remain constant over the next 15 years. ${ }^{113}$

The average number of children per family and the persons per family in Canada has steadily declined since the 1970s. At the same time, the number of childless families has steadily risen since the 1970 s from 26.8 percent in 1971 to 35.1 percent in 1991 .

Since 1971, the number of women aged 30 to 55 that have no children has increased from 9.2 percent in 1971 to 12.6 percent in 1991. The average number of children per woman aged 30 to 55 has also continually decreased since 1941 to a low of 2.11 children per woman. ${ }^{114}$

Based on these statistics, we assume that if a couple has children they will have two children. Although several statistics indicate a family size lower than two, this is because families of all sizes (including childless ones) are included to produce these statistics. As it is not physically possible to have fractional family sizes, we assume two-adult, two-child families in these cases.

\section{Age at Birth of First and Second Children}

The mean age of fertility refers to the average age of motherhood or childbearing. According to experts, the rise in the average age of motherhood is explained by two major factors. First, the average age of first motherhood in Canada has continually risen since the 1960s, indicating that Canadian women are waiting longer to have their first child. Second, older women are making up for their postponed first birth, thus increasing the average age statistic. ${ }^{115}$

In 1991, the average duration between first and second births in Canada was 3 years; by 1992 that figure had dropped to 2 years. The average number of years between births of the first and second born child is calculated by subtracting the median age of mothers at firstborn from the median age of mothers at the birth of the second born. The median ages are taken from all mothers who had a firstborn and all mothers who had a second child in the given year. It is not exactly the difference of the median ages of an individual mother between her first and second born children. ${ }^{116}$

Based on these statistics, we assume that the deceased would have had his or her first child two years after marrying and their second child two years after the first child. 91F0015MPE (Ottawa: Statistics Canada, 1996), Table Al.

iis Family Over the Life course, supra note 107, Table 2.8 .

i1s A. Romaniuc, "Fertility in Canada: Retrospective and Prospective" (1991) 18 Canadian Studies in Population 56; S. Loh. \& B. Roum, "Delayed Child-Bearing in Canada: Trends and Factors" (1990) 46 Genus 147. 


\section{F. Personal Expenses deduction for families of Various Sizes}

\section{Personal Expenses Deduction in Four-Member Families}

The deductions in Semenoff $f^{17}$ and Harris ${ }^{118}$ ranged from 25 to 33 percent, with the latter applicable in the case of a married man with no children and the former relevant for a married man with two children. The 33 percent deduction is explained in Kemp:

The Fatal Incidents Act dependency would be about 75 per cent. of net earnings. The items of joint expenditure, namely, rent or mortgage interest, rates, heating, gas, electricity, telephone, motor car, TV etc., would not significantly increase with the increased family unit, and so would remain at about 33 per cent. of net earnings. One quarter of this joint expenditure is to be added to living expenses solely attributable to the victim, say, 8 percent. The resulting deduction for living expenses would be 25 per cent. plus 8 per cent. i.e. 33 per cent. ${ }^{11 \prime}$

We have attempted to verify the 33 percent figure for the deceased using Statistics Canada's Family Expenditure in Canada, $1992^{120}$ and Family Expenditure in Canada, 1996. ${ }^{121}$ In Appendices A and B, we divide various expenditure categories into fixed (denoted as (f)) and variable (denoted as (v)) costs, ${ }^{122}$ with the main criterion for the division consisting of whether or not the expenditure would vary when additional family members are present in the household. In many respects, this division reflects the discussion in Kemp above, but is based on expenditure categories that are specific to Canadian households. For the most part, this division follows the American division of joint and variable expenditures based on Bureau of Labor Statistics most recent Consumer Expenditure Survey. ${ }^{123}$

In conducting the analysis detailed in Appendices $\mathrm{A}$ and $\mathrm{B}$, we find that fixed costs represent 53 to 57 percent of total expenditures for four-person and two-person households in Canada in 1992 and 1996. ${ }^{124}$ This conclusion allows us to now calculate the "lost years" deduction (personal living expenses deduction) similar to the Semenoff and Harris methodology. The steps are as follows:

Semenoff, supra note 30.

Harris v. Empress Motors Lid., [1983] 3 All E.R. 561.

Supra note 67, c. 26 at $26-002 / 8$.

Supra, note 59, Table 17.

Supra note 58, Table 9. This is the most recent survey completed by Statistics Canada on all twoperson households in Canada and the only one since 1992.

The four-digit codes pertain to Statistics Canada's expenditure category coding. There were some slight changes from 1992 to 1996.

Supra note 56. This survey, made available by the Bureau of Labor Statistics in December 1996, is the most current and comprehensive consumption data available for use in 1998 (see Lierman, Patton and Nelson, "Patton-Nelson Personal Consumption Tables Updated" (1998) 11(1) Journal of Forensic Economics 3). The main exception is that the American studies that determine personal consumption and dependency rates exclude expenditures on shelter from their joint expenditure ratios.

124 This ratio is similar to the ratios calculated in Lierman, Patton and Nelson, ibid, when four-person houscholds earnings $\$ 40,000$ to $\$ 49,999$ are considered, and shelter expenses are added back. 
a. Estimate the personal consumption rate for the deceased based on family composition. Table I-3, above in Section II.C.2.a., summarizes estimates of personal consumption rates by family size. For one adult in a four-person household, the personal consumption rate is 21 percent. (This is comparable to the 25 percent personal consumption rate described in Kemp, based on a 75 percent dependency rate.)

The personal consumption rate refers to the percentage of the deceased's income that he or she required to maintain his or her (and not other family members') standard of living. It includes some fixed items of expenditure (divisible ones), but not all of them (such as indivisible items such as a house or a car).

The percentages summarized in Table I-3 above suggest that, on average, 21 percent of family income can be attributed to a deceased adult when there are three survivors (an adult and two children).

b. Add the deceased's share of joint expenditures based on the fixed expenditures in Canadian households. We calculate this as one-quarter of the fixed expenditures (53 to 57 percent) shown in Appendices $A$ and $B$, equal to approximately 14 percent. (This is comparable to the 8 percent for joint expenditures attributed to one member of a four-person household in Kemp above, based on 33 percent divided by four.)

c. Add components (a) and (b). This is equal to 35 percent (=21+14 percent).

On this basis, we have estimated the deceased's lifetime earning capacity after a 35 percent "lost years" deduction when there are three dependents. This is exactly the percentage adopted by Sulyma J. in Duncan (Q.B.). ${ }^{125}$

\section{Personal Expenses Deduction in Three-Member Families}

If the deceased had only one child, or we are calculating the "lost years" deduction when there are only three family members living at home (i.e., after the eldest child in a four-person family has attained self-sufficiency), then we use a 44 percent "lost years" deduction based on the same methodology as above but modified for family size:

a. Estimate the personal consumption rate for the deceased based on family composition. Table I-3 above summarizes estimates of personal consumption rates by family size. For one adult in a three-person household, the personal consumption rate is approximately 26 percent. (This is almost exactly equal to the 25 percent personal consumption rate described in Kemp and Kemp, based on a 75 percent dependency rate.)

b. Add the deceased's share of joint expenditures based on the fixed expenditures in Canadian households. We calculate this as one-third of the fixed 
expenditures (53 to 57 percent) shown in Appendices $A$ and $B$, equal to approximately 18 percent.

c. Add components (a) and (b). This is equal to 44 percent $(=26+18$ percent).

\section{Personal Expenses Deduction in One- or Two-Member Families}

The other fact pattern that can occur involves middle-aged plaintiffs who die without dependents or if there is evidence to suggest that the deceased would have coupled but remained childless. In these cases, we use a 50 percent "lost years" deduction based on the case law summarized in Table I-1 above in Section II.C.l.a. and the fact that the methodology described above would lead to a personal consumption rate ranging from 31 to 59 percent, for a midpoint of 50 percent. This includes the deceased's personal consumption rate and his or her share of fixed/joint expenditures. We do not attribute one-half or all of the joint/fixed/indivisible expenditures to the deceased in one- or twomember households, as we assume that the bulk of these types of expenditures would result in enduring capital items or luxury items; and the savings accumulated would be a larger share of income.

In practice, family size normally varies over the life cycle, and given that deductions for personal living expenses are based on personal consumption rates (which vary by family size) and the deceased's proportionate share of fixed and variable family expenditures (which would affect the deceased's proportionate share), the deduction for personal living expenses in a single case may be fluid over the course of the deceased's projected life cycle. Table I-4 below provides an example of how the "lost years" deduction could vary over the projected life cycle for a deceased minor. The derivation of these deductions and the statistics relied upon to support these life events can be found in Appendices A through C and Section II.E.

Table 1-4:

Changes in Deductions Over the Life Cycle (female/male)

\begin{tabular}{|c|c|c|c|}
\hline Life Events/Transition & $\begin{array}{c}\text { Number of } \\
\text { People in } \\
\text { the } \\
\text { Household }\end{array}$ & $\begin{array}{c}\text { Age at Which We } \\
\text { Assume Life Events } \\
\text { Would Occur for } \\
\text { the Deceased }\end{array}$ & $\begin{array}{c}\text { "Lost years" } \\
\text { Deduction Applied } \\
\text { to the Deceased's } \\
\text { Potential Earnings }\end{array}$ \\
\hline From being single to getting married & 1 & Birth - 26/28 & $50 \%$ \\
\hline From getting married to having Ist child & 2 & $26 / 28-28 / 30$ & $50 \%$ \\
\hline Ist child to 2nd child & 3 & $28 / 30-30 / 32$ & $44 \%$ \\
\hline Until 1st child leaves home & 4 & $30 / 32-50 / 52$ & $35 \%$ \\
\hline Until 2nd child leaves home & 3 & $32 / 34-52 / 54$ & $44 \%$ \\
\hline Empty-nesters & 2 & $52 / 54-$ retirement & $50 \%$ \\
\hline
\end{tabular}

In a situation where the deceased's family size (and therefore personal living expenses deduction) would have varied over the course of his or her life span, it is possible to provide a series of calculations that account for varying "lost years" 
deductions, rather than a single "lost years" deduction, over the course of the deceased's projected life cycle.

\section{Personal Expenses Deduction in Low-income Households}

When the deceased is from a low-income household, the deduction for personal living expenses will be, on average, higher than that for a deceased individual from a middle- or high-income household. The data in Appendix $\mathrm{C}$ shows that people in lowincome households spend a larger percentage of their income on fixed ${ }^{126}$ expenditures ( 51 percent to 61 percent) than individuals in middle-income households (53 percent to 56 percent). For example, the families outlined in Appendices A and B would be considered "middle-income," and the families outlined in Appendix C would be considered "low-income."

Also, the deduction for personal expenses is higher for deceased individuals in lowincome families because their savings ${ }^{127}$ are lower, "enduring" capital assets are less likely to be accumulated, or if they are accumulated, would be of lower value, and luxury items would be purchased less frequently. Moreover, the impact on intra-family allocation could cause the deceased to spend more or less on other family members. ${ }^{128}$ The actual increase in the personal expenses deduction for low-income households will depend on an examination of the data and the particular evidence in the cases. As a result, the "lost years" deduction for a low-income earner will be higher than that for a middle-income earner to reflect the reality of his or her financial circumstances. This in turn will result in lower awards for loss of a chance of future earnings for individuals from low-income households, regardless of the fact that their actual projected future income would be lower in any event than that of a middle- or high-income earner.

\section{BROOKS V. STEFURA}

In Duncan (Q.B.), Sulyma J. commented on the recent decision in Brooks v. Stefura, ${ }^{129}$ which the Defendant heavily relied on in its submission in Duncan (Q.B.). Aside from its treatment in Duncan (Q.B.), Brooks is a significant refinement of Alberta case law because it was the first Alberta case to address the interrelationship between loss of dependency claims based under the Fatal Accidents Act and the deceased's estate's claim for a loss of a chance of future earnings pursued under the Survival of Actions Act. The Defendant in Duncan (Q.B.) noted that Belzil J. applied an 80 percent "lost years" deduction to the loss of a chance of earnings award in Brooks and argued

126. This occurs because many "basic" items fall into the fixed rather than variable categories.

127 Note that households in Appendix C spend (dissave) more than their after-tax income - denoted by the last line in the table called "\% of Total Expenditure over Total Income (After-tax)," which show percentages in excess of 100 percent.

12x For example, the data in Appendices A, B, and C from Statistics Canada's Family Expenditure Survey. 1996, supra note 58, shows that for a middle-income 2-person household, 22.5 percent of the total family expenditure is allocated to shelter. In contrast, a low-income 2-member household (where household income is between $\$ 15,000$ and $\$ 20,000$ ) allocates 28.0 percent of the total family expenditure to shelter. 
that a similar deduction should be applied in Duncan (Q.B.). As Sulyma J. rightly pointed out, Brooks is distinguishable on its facts:

The deceased Brooks was 37 years old at the time of his death, had an employment, income and expenditure history and dependents. Dean Duncan, a teenager at the time of his death, had none of the above. Thus, I am not faced with a dependency claim and I cannot find the deceased would have fathered more children than a statistical average. Further, there is no evidence of a particular lifestyle from which I could conclude Dean Duncan would have incurred future debt obligations of the kind in Brooks beyond those attributed statistically to him or beyond those expenses attributed to him by the statements in Harris and Semenoff. On that basis I decline to expand lost years deductions in this case in the manner adopted by Mr. Justice Belzil, the evidence does not support it. ${ }^{\text {14t }}$

In order to provide some context for Sulyma J.'s comments and to discuss the implications of Brooks vis- $\dot{a}$-vis claims for loss of a chance of future earnings, the unique facts of Brooks must be examined in some detail. Attention will be given to the dependency loss methodology and calculations in Brooks as well as the loss of a chance of earning methodology and calculation as the two are inextricably intertwined in Belzil J.'s judgment.

\section{A. BROOKS V. STEFURA - THE FACTS}

Mr. Brooks was married and had two children - he was killed instantly in a motorcycle accident on 15 August $1990 .{ }^{131}$ At the time of the accident, Mr. Brooks and his wife were separated and the matrimonial home had been listed for sale. ${ }^{132}$ Mrs. Brooks had been seeing another man prior to the accident and continued to do so after the accident; the deceased raised no objection to Margaret Brooks being with another man, and no evidence was provided to the court that the deceased was upset with her for seeing someone else. Mrs. Brooks testified that her reconciliation with $\mathrm{Mr}$. Brooks would only have been possible if the deceased had agreed to undergo counselling - no evidence was presented to the court that indicated that Mr. Brooks ever undertook counselling or even consented to attend counselling.

Mrs. Brooks had consulted a matrimonial lawyer earlier in 1990 and that lawyer's complete file was exhibited before the court. Belizil J. noted that it was marked in the lawyer's file that he had inquired of Mrs. Brooks whether she thought there was any possibility of reconciliation at that time, and that she had replied in the negative. During the separation, Mrs. Brooks was the prime residential custodial parent of the children of the marriage, though neither Mr. Brooks nor Mrs. Brooks had formally commenced divorce proceedings prior to the accident.

After reviewing the evidence put before him, Belzil J. determined that

Duncan (Q.B.), supra note 4, para. 34 [emphasis added].

At the time of his accident, Mr. Brooks was 37 years old, Mrs. Brooks was 32 years old, and their children were aged 6 and 3 .

The Listing Agreement to sell the matrimonial home, dated 8 May 1990, was renewed by Mr. Brooks for a further period of 90 days on 8 August 1990, just seven days before the accident occurred. 
the evidence overwhelmingly establishes that the reality which would have arisen had this accident not occurred is that the parties would have divorced and that Margaret Brooks would have been the prime residential custodial parent with the deceased being granted liberal and generous access. As an incident of divorce, the deceased would have been required to pay spousal support as well as child support. ${ }^{13}$

This finding was central to the loss of dependency calculations for Mrs. Brooks and her children, as Mrs. Brooks' loss of dependency was ultimately calculated according to the probable spousal maintenance that she would have received from Mr. Brooks upon divorce. Similarly, the Brooks children's loss of dependency was calculated according to the Federal Child Support Guidelines. ${ }^{134}$

The parties to the action agreed that the likely spousal maintenance that Mrs. Brooks would have received upon divorce would have been $\$ 500$ per month for a total period of five years (1 September 1990 to 31 December 1995), further agreeing on a total spousal support calculation of $\$ 30,000$, which constituted the gross dependency loss of Mrs. Brooks. Mrs. Brooks' accelerated estate inheritance $(\$ 4,619)$ was deducted from this amount, resulting a net dependency recovery of $\$ 25,381$, exclusive of prejudgment interest. A tax gross-up was not applied to any portion of this amount, on the basis that no future payments to Mrs. Brooks were involved.

Addressing the application of a divorce contingency to Mrs. Brooks' loss of dependency award, the court concluded that "it would not be appropriate to determine a contingency reduction for divorce in a situation wherein I am able to determine on the evidence that divorce was not a mere contingency but rather a near certainty."135

With regards to the calculation of child support, "the parties agreed, for the purposes of this action, that the Guideline amounts should be utilized, and the parties were able to reach agreement on the amount of basic child support in accordance with the Guidelines." 136 The court determined that Mr. Brooks would have been obligated to pay his children $\$ 115,499$ in basic child support, or $\$ 57,750$ per child, based on the Guidelines.

Additionally, Belzil J. commented in Brooks that "[i]n my view, a Court assessing child support would assess 5.7 extraordinary expenses in the amount of $\$ 50$ per month child for the same period."137 Accordingly, each Brooks child was eligible for $\$ 7,400^{138}$ under s. 7 of the Guidelines for extraordinary expenses.

At issue between the parties was Mr. Brooks' portion of post-secondary educational costs for his children as per s. 7 of the Guidelines. The court reviewed the academic history of the children and determined that Meghan Brooks, being an honours student, would likely move on to university, while Daniel Brooks would be more likely to attend a technical college rather than university. Accordingly, Belzil J. awarded Meghan

\footnotetext{
$133 \quad$ Brooks, supra note 9 at 343.

134 S.O.R./97-175 [hercinafter Guidelines].

i3s Ibid. at 343 .

$136 \quad$ Ibid. at 345

$137 \quad$ Supra note 9 at 345.

$138 \$ 7,400=148$ months (1 September 1990 to 31 December 2002$) \times \$ 50 /$ month.
} 
Brooks and Daniel Brooks $\$ 6,000$ and $\$ 4,000$ respectively for post-secondary educational costs. The court did not apply a tax gross up to any of the child support amounts.

Mrs. Brooks and each of her children also advanced loss of housekeeping services claims under the Fatal Accidents Act; however, the court rejected these claims on the basis that as "divorce was a virtual certainty, no possible housekeeping claim arises." 139

\section{B. BROOKS V. STEFURA - AN ECONOMIC ANALYSIS}

The methodology used by the court in Brooks was as follows:

1. Assuming that the deceased and his or her spouse were experiencing martial difficulties at the time of the accident, begin with a threshold determination of the likelihood of reconciliation between the parties;

2. If one finds that there was a possibility of reconciliation between the parties, however remote, calculate a standard loss of dependency for the dependants using the joint dependency formula and then apply appropriate contingency reductions for divorce and remarriage, given the circumstances of the case;

3. If one finds that there was virtually no possibility of reconciliation between the parties, calculate the gross loss of dependency for the surviving spouse based on the probable spousal support that he or she would have received but for the accident. Specifically, determine what amount of monthly spousal support the surviving spouse would have received from the deceased and how long this maintenance would have continued. As per Davies v. Powell Duffryn Associated Collieries Ltd., ${ }^{140}$ deduct the surviving spouse's accelerated inheritance from his or her gross dependency loss to arrive at a net dependency loss calculation;

4. If there are children claiming loss of dependency in the context of inevitable divorce between the parties, their dependency loss is calculated according to the Federal Child Support Guidelines. One must determine how long the child support would have been provided and the monthly child support award. The monthly child support award will include:

a) a basic child support amount prescribed under the Guidelines according to the payor's gross income;

b) an additional $\$ 50.00$ per month per child ${ }^{|4|}$ for the duration of the child support; and 
c) any specific special or extraordinary expenses according to 5 . 7 of the Guidelines, such as child care expenses, medical or dental insurance premiums, health-related expenses, post-secondary school expenses, or expenses for extracurricular activities; and

5. Regardless of the state of the deceased's marriage and/or his or her marital status, if the deceased's estate is claiming an award for the deceased's loss of a chance of future earnings as per Duncan Estate v. Baddeley ${ }^{i 42}$ while the deceased's dependent(s) is/are simultaneously advancing a loss of dependency claim(s), the method of calculation is as follows:

a) calculate the employment income that the deceased would have earned from the date of the accident to the projected date of retirement;

b) calculate the present value of the deceased's obligations over his anticipated working life, using the appropriate discount rate. The obligations which must be accounted for include:

i) income tax;

ii) the future cost of a life;

iii) "future obligations"; 143 and

iv) future debts; ${ }^{144}$

c) After deducting from lost employment income the present value of the cost of the deceased's obligations [(b) above] over his anticipated working life, including the present value of future obligations [(b(iii) above], one must then deduct the present value of the dependency claim(s) for the surviving spouse and/or children as calculated based on (3) and (4) above. The resulting award is the amount available to the deceased's estate for loss of a chance of future earnings (i.e., a "Duncan v. Baddeley type" claim).

Translated into equation form, in Brooks:

Duncan award for estate $=\{$ [Lost earnings - (income tax + future cost of a life + future obligations + future debts)] - Net dependency award for deceased's dependents ?

Supra note 4.

In Brooks, Belzil J. noted that "[i]n my view there was a strong likelihood that the deceased would have formed one or more relationships with other women had he not been killed, and unquestionably, the deceased, if he entered into other relationships, would find it more difficult to spend as much time with his children as he did prior to the separation and subsequent death. Indeed the partics, for the purposes of this action, agreed that the deceased's accumulative statistical likelihood of remarriage was 63 percent." (Supra note 9 at 347.) The fact that Mr. Brooks would have possibly entered into other relationships and perhaps even have been responsible for other children in the future was considered to be a "future obligation."

In Brooks, the court observed that "It is highly probable that but for his untimely death the deceased would have continued the same lifestyle which would have entailed incurring debts to pursue that lifestyle." (Supra note 9 at 353 .) This will be discussed in the next section. 
In Brooks, the court applied the above equation in the following manner:

a) It was determined that Mr. Brooks' total take-home pay was $\$ 859,177$ for the period of 1 September 1990 to 11 February 2015. ${ }^{145}$ Factored into this calculation was an assumed retirement age of 62 and a 3 percent discount rate;

b) Mr. Brooks' obligations [(5) above] under his anticipated working life were concluded to consist of:

i) income tax (specific amount not given in judgment);

ii) future cost of a life; $;^{146}$

iii) future obligations, which consisted primarily of a strong likelihood (63 percent) that Mr. Brooks would have remarried or entered into one or more common law relationships, which would have given rise to the further contingency of fathering more children or voluntarily entering into a situation wherein he agreed to become responsible for other children as a result of a relationship with the mother of the children; and

iv) future debts "over and above ordinary family debt associated with, for example, mortgage financing." Belzil J. also commented that "it was acknowledged in evidence before me that prior to his untimely death the deceased had made a number of purchases for discretionary items like motorcycles and electronic equipment which required bank financing." ${ }^{147}$

In light of the foregoing, the court determined that an 80 percent overall deduction should be made from Mr. Brooks' total take home pay, to account for (5)(b) above, thereby resulting in a figure after deductions of $\$ 171,823,{ }^{148}$ which represented Mr. Brooks' lost employment income, less the present value of the deceased's obligations over his working life. This amount was also referred to by Belzil J. as the "available surplus."

c) From the available surplus of $\$ 171,823$, Belzil $\mathrm{J}$. then deducted the net dependency claims (based on spousal and child support in (3) and (4) above) of Mrs. Brooks, Meghan Brooks, and Daniel Brooks in the amounts of

11 February 2015 was Mr. Brooks' assumed date of retirement.

146 Belzil J. elaborated on this item to include expenditures that Mr. Brooks would have incurred in order to earn his living (specific amount not given in judgment) and expenditures that Mr. Brooks would have incurred in order to maintain his standard of living (specific amount not given in judgment) (Supra note 9). 
$\$ 25,381,,^{149} \$ 71,150^{150}$ and $\$ 69,150^{151}$ respectively, implying a "Duncan v. Baddeley type" award of $\$ 6,142 .^{152}$

Notably, Belzil J. applied the "personal expenses" deduction of 80 percent before deducting the original family's dependency awards; but, it appears conceivable that the calculation could be undertaken in the opposite way: to deduct the dependency award, and then review the situation to see if there is a residual "Duncan v. Baddeley type" award. If the opposite method had been used in Brooks, the "Duncan v. Baddeley type" award would have equalled $\$ 138,700$ (see Section III below). This is reinforced by the realization that Belzil J.'s method worked only because he had assumed divorce by the trial date; if he had reduced Mr. Brooks' lifetime income by 80 percent and then tried to deduct the dependency awards (assuming an intact family), he would not have had enough of a surplus to even grant the original dependents a Fatal Accidents Act claim. Indeed, Belzil J.'s decision would have implied that Mr. Brooks would have squandered almost all ( 80 percent) of his income on himself and a fictitious second family. While this might have been the result Belzil J. believed to be representative for the Brooks family, it still leaves a methodology that simply does not work for dependents of intact families. If a formula cannot be applied in all fact situations (or at least render a true result), it may not be of much assistance.

Appendices D and E provide brief analyses of the spousal support and child support calculations in Brooks. While these calculations were ancillary to the calculation of the award for loss of a chance of future earnings, Belzil J. did label the spousal and child support amounts to be financial obligations to be considered when he assumed the family would have divorced by the date of trial. This data may be useful in such fact situations, and when Fatal Accidents Act and Survival of Actions Act claims are advanced simultaneously and the "Duncan v. Baddeley type" award is calculated from the residue left after remarriage and divorce probabilities are applied (see below).

\section{THE "LOST YEARS" DEDUCTION IN BROOKS v. STEFURA}

As indicated in Section II.B. above, Belzil J. applied an 80 percent "lost years" deduction in the Brooks case. This is a much larger deduction than that advocated by the Alberta Court of Appeal in Duncan (C.A.) (50 percent to 70 percent) and by Sulyma J. in Duncan (Q.B.) ( 35 percent). It has been noted that

the decision in Brooks v. Stefura ... departs from the principles of assessment adopted in Duncan Estate. First, it is clear from the Harris decision that only the deceased's estimated spending on himself

$\$ 25,381=\$ 30,000$ (spousal support) $-\$ 4,619$ (accelerated inheritance).

$\$ 71,150=\$ 57,750$ (basic child support) $+\$ 7,400$ (s. 7 child support) $+\$ 6,000$ (post-secondary school expenses).

151 $\$ 69,150=\$ 57,750$ (basic child support) $+\$ 7,400$ (s.7 child support) $+\$ 4,000$ (post-secondary school expenses).

152

Note that the figure of $\$ 6,142$ was not actually specified in the Brooks decision; rather, it was derived by applying the Belzil J.'s formula to the facts in Brooks. Plaintiff's counsel has advised that the "Duncan v. Baddeley type" award in Brooks was in fact reduced even further presumably, this is because the dependency award for Mr. Brooks' dependents attracted prejudgment interest. 
or herself is to be deducted from net earnings. Belzil J. reduced the estate's award under the Survival of Actions Act on the basis of the likelihood that the deceased would have started a new family, and would have had increased obligations to meet with his limited income. If the Harris approach were employed, this assumption would lead to a greater award to the estate given that the deceased would have to reduce his personal consumption to meet the financial burden of his second family.

Second, in regard to greater deductions for "excessive" personal spending, the Court of Appeal in Duncan Estate refused to adopt an approach which failed to award amounts to the estate which included the discretionary spending of the deceased.

...[1]t scems to me that this would not be a correct statement of what I earned in my lifetime. My life-savings would tell one what I spend during my life on my pleasure, as opposed to what I had to spend in connection with the earning of my income.

The flaw in the "lost savings" approach is that it is heir-centred, not victim-centred. It asks what the heirs lost, not what the victim lost. But the suit here is not for the loss to the estate, it is a suit by the victim for his loss, a claim that by operation of statute survives his death and can be made by his estate for him. Worse, it has the air about it of an attempt to undermine the statute. As a result of this flaw, the approach will fail to take into account what has been called "discretionary" spending, like holidays and entertainment and other "treats." It will also fail to take into account gifts to children and spouses, and thereby underestimate even an heir-centred award. ${ }^{153}$

The inappropriateness of the 80 percent "lost years" deduction in Brooks to the Duncan (Q.B.) case was reinforced by Sulyma J.'s comment that

Mr. Justice Belzil did not confine deductions of expenses to living expenses of the deceased. He made further deductions for future obligations he found the deceased would have incurred had he not died. However, in doing so he stated a significant factor in the case before him was the presence of a dependency claim which had to be first deducted from the gross value of the estate. The deduction necessarily contained a factor of known expenditure on the dependant children and spouse. Further, he made other deductions factually on finding that it was probable the deceased would have fathered more children than he already had, and on the basis of evidence that prior to his death the deceased had made a number of purchases of items such as motorcycles and electronic equipment, which in turn required bank financing. On that basis Justice Belzil found it highly probable that, but for the deceased's death, he would have continued the same lifestyle which would have entailed incurring debts. He found this to be over and above ordinary debt and, it was on these facts he found an 80 percent reduction against future earnings to be appropriate. ${ }^{1 \mathrm{~s}}$

Based on what he knew about Mr. Brooks, Justice Belzil deducted 80 percent for income taxes and future "obligations" (consisting of expenses arising from various circumstances and future debts).

In most circumstances, however, the author would submit that this would be an excessive deduction. This is for several reasons: 
1. There could be an argument to increase the deceased's personal expense deduction for the types of items referred to by Belzil J. (such as motorcycles and electronic equipment) if it could be shown that:

a) Such expenditures depleted the deceased's savings (and this appears to have been the case in Brooks, given that Belzil J. referred to them as "debts");

b) Such expenditures would not have become "enduring capital items"; and

c) Such expenditures are not considered to be part of luxuries or discretionary items.

If the above descriptions do apply to the future "obligations" or "debts," it would appear that Belzil J.'s methodology is contrary to the principles underlying "Duncan v. Baddeley type" awards, because such obligations or debts should form the loss to the estate.

2. The economics of personal consumption rates clearly show that individuals spend only 31 percent of their income on their personal "obligations," and less if they have children.

The Duncan v. Baddeley principles have emphasized that the existence of additional family members (such as a second family) should cause the deduction attributable to the deceased's personal expenses to decrease, not increase, and this is consistent with the decrease in personal consumption rates in Fatal Accidents Act cases as family size increases.

3. Sulyma J., in Duncan (Q.B.), endorsed the method for calculating living expenses (equivalent to Belzil J.'s characterization of "obligations") during the "lost years" in that it takes into account the presence of future marriage and possible dependents. In contrast to Belzil J., who believed that such dependents would increase the deceased's consumption (and thus decrease the available surplus remaining in the estate), Sulyma J. confirmed that the presence of dependents decreases the deceased's consumption, thereby increasing the available surplus. In other words, a "Duncan v. Baddeley type" calculation represents the loss to the estate net of the deceased's expenditures applicable only to himself or herself; expenditures on others are not considered to be deductible personal expenses.

Sulyma J. was unequivocal in noting that expenses made by the deceased on his or her family should not be included in personal living expenses, except to the extent that the deceased would have incurred a proportionate share of the family's fixed assets. Sulyma J.'s approach was congruent with that of Kerans J.A. in his clear rejection of the "lost-savings approach." In contrast, Belzil J. considered the deceased's future (potential) familial obligations to be a consideration in determining the "lost years" deduction in Brooks, noting that 
[t]hus in calculating an award on the basis of Duncan v. Baddeley, it is necessary to calculate the present value of the deceased's obligations over his anticipated working life, using the appropriate discount rate. The obligations which must be factored in are income tax, the future cost of "life." and the present value of future obligations which would include future debt obligations and the possibility of the deceased having another spouse and/or more children. ${ }^{135}$

4. Belzil J. explicitly accounted for the deceased's "future obligations" in the personal expenses deduction to increase it to 80 percent in Brooks, which is contrary to Kerans J.A.'s remark in Duncan (C.A.) that

the law requires that we calculate the expenses that the victim would have incurred in the course of earning the living we predict he would earn. That sum will vary with the kind of employment, and the state in life of the victim. ${ }^{15,}$

In fact, Kerans J.A. unambiguously differentiated what one spends during his or her life on pleasure from that which one spends in connection with earning income, noting that

[m]y life savings would not tell one what I spent during my life on my pleasure, as opposed to what I had to spend in connection with the earning of my income. ${ }^{157}$

In contrast, Belzil J. noted that

[i]t was acknowledged in evidence before me that prior to his untimcly death the deceased had made a number of purchases for discretionary items like motorcycles and electronic equipment which required bank financing. Indeed this was a source of stress within the marriage as noted above.

The evidence before me establishes that the deceased was a very active person who clearly enjoyed outdoor life.

In my view, it is highly probable that but for his untimely death the deceased would have continued the same lifestyle which would have entailed incurring debts to pursue that lifestyle. This would be over and above ordinary family debt associated with, for example, mortgage financing. For the purposes of a calculation under Duncan v. Baddeley, this has to be calculated as the present value assessment of future debt obligations. ${ }^{\text {is }}$

Kerans J.A's remarks suggest that discretionary items, as described by Belzil J., would form part of the estate claim, not the personal living expenses deduction. 
Additionally, given that claims for loss of a chance of future earnings are pursued under the Survival of Actions Act, I would suggest that Sulyma J.'s approach of making the award in Duncan (Q.B.) without regard for who the deceased's beneficiaries were was more congruent with the aim of survival legislation, as awards are made under the Survival of Actions Act for the benefit of the deceased's estate. ${ }^{159}$ In contrast, Belzil J. considered who the deceased's beneficiaries were when calculating the "Duncan v. Baddeley type" award in Brooks in trying to ensure no duplication in the Fatal Accidents Act and Survival of Actions Act awards:

In this case, the dependents under the Fatal Accidents Act are the same as the beneficiaries of the deceased, but clearly, this will not always be the case.

It was conceded by counsel for the Plaintiffs that the dependency claim under the Fatal Accidents Act has to be deducted from the gross value of the estate such that there is to be no double recovery. Implicit in this is the acceptance that dependency claims are notionally what the deceased would have provided by way of support had he survived, and must be viewed as an obligation. Also implicit in this is that a dependency claim has priority over the estate claim in the sense that if there were no realistic surplus after calculating a dependency claim, there could be no recovery under Duncan v. Baddeley. ${ }^{161}$

Given the Alberta Court of Appeal's remarks about spending on family members forming part of the deceased's claim, I would have assumed that Belzil J. would have contemplated an award for loss of a chance of future earnings in Brooks without regard to who Mr. Brooks' beneficiaries were, even if a duplicate award would have occurred - and it will only occur in unique cases like Brooks, where divorce is presumed to be inevitable (and, ironically, a divorced spouse would presumably not be a beneficiary to the estate), or when remarriage or divorce probabilities are applied. In his attempt to avoid double recovery for Mr. Brooks' dependents, who also happened to be Mr. Brooks' beneficiaries, Belzil J. did not discuss a principle that underlies survival legislation and may have blurred the primary distinction between Fatal Accidents Act claims and Survival of Actions Act claims, that being

[s]urvival actions are brought to vindicate the rights of the deceased, whereas fatal accident claims vindicate the rights of his or her statutory dependents. ${ }^{161}$

\section{OVERLAP BetweEn Claims UNDER THE FATAL ACCIDENTS ACT AND THE SURVIVAL OF ACTIONS ACT}

Belzil J. took the opposite approach of what may be done in cases where dependents exist and both the Fatal Accidents Act and Survival of Actions Act would be invoked.

i6) Cooper-Stephenson, supra note 82 at 725. 
In such cases, we presume the dependents' claims would take priority, such that the award would be calculated as follows:

Survival of Actions Act ("Duncan v. Baddeley type") award = present value of the deceased's after tax income - dependency award - personal expenses ("lost years") deduction.

Applying this alternative formula to the facts in Brooks would result in the following calculation:

"Duncan v. Baddeley type" award = present value of the deceased's after tax income - dependency award - personal expenses ("lost years") deduction

Where:

Present value of Mr. Brooks' after-tax income

$=\$ 859,177$

Net value of Mrs. Brooks' dependency loss

$=\$ 25,381$

Basic child support

$=\$ 115,499$

Extraordinary child support expenses

$=\$ 14,800$

Post-secondary education expenses for children

$=\$ 10,000$

Personal expenses deduction

$=80 \%$

"Duncan v. Baddeley type" award $=[\$ 859,177-(\$ 25,381+\$ 115,499+\$ 14,800+\$ 10,000)] x$

$$
\begin{aligned}
& (1-0.80) \\
& =\$ 138,700
\end{aligned}
$$

Note that this amount is exactly equivalent to:

$(\$ 859,177-\$ 25,381-\$ 71,150-\$ 69,150) \times(1-0.80)$

However, because the personal expenses deduction is based on personal consumption rates (which are the inverse of dependency rates), there will be no residue left to make a "Duncan v. Baddeley type" award, except in cases where remarriage and divorce probabilities are incorporated.

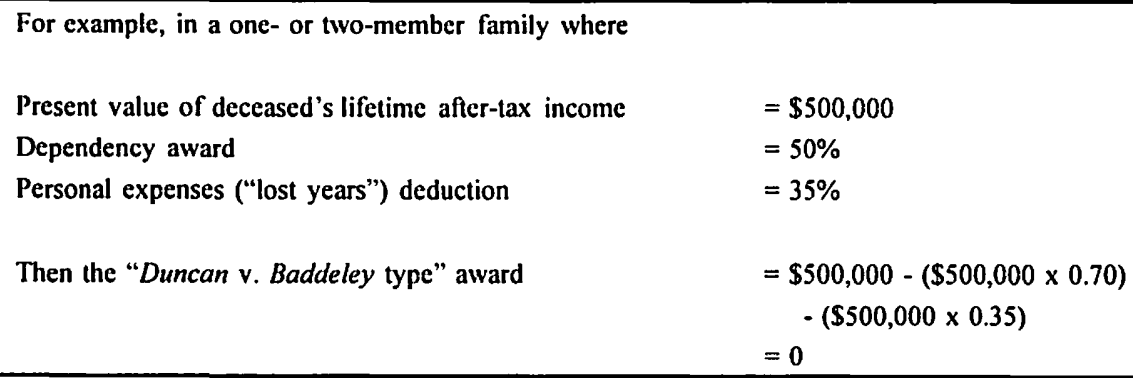


in mind that remarriage and divorce contingencies are routinely applied in Fatal Accidents Act cases. Implicitly, these contingencies reduce the dependency below the rates determined with regard to personal consumption rates. The calculation is approached the following way:

For remarriage:

Survival of Actions ("Duncan v. Baddeley type") award = (present value of difference in lifetime income with and without remarriage probabilities) - personal expenses deduction.

For divorce:

Survival of Actions ("Duncan v. Baddeley type") award = (present value of difference in lifetime income with and without divorce probabilities) - personal expenses deduction - spousal support - child support

Importantly, these approaches can be used in all fact situations. For instance, Belzil J. could have used the "divorce" formula noted above in Brooks; the unique fact situation would have simply meant that the personal expenses deduction and spousal and child support would have been deducted without calculating a dependency award weighted by divorce probabilities.

\section{Future IMPLiCATIONS OF THE DUNCAN V. BADDELEY DeCision}

The Alberta Law Reform Institute squarely addressed claims for the loss of a chance of earnings in its Final Report No. $76 .^{162}$ That report ultimately concluded that claims for a loss of a chance of earnings should be statutorily barred in Alberta by an amendment to the Survival of Actions Act, with the change not being retroactive. One author comments:

[T] he Law Reform Institute has merely supplanted its own views of "justice" for those of the Court. Clearly, the Court of Appeal in Galand Estate and again in Duncan Estate chose an interpretation of the Survival of Actions $A C l$ which addressed a manifest justicc. The interpretation it chose does not torture the words in Section 5 and accords with the Court's view of policy. It is an interpretation which corrects an inherent injustice where previously compensation based only on the timing of the death of the individual as a result of the injuries. If death occurred prior to trial, no compensation for future loss of earning capacity was paid whereas if the plaintiff survived, only to die after trial, full compensation for the lost years was paid. The Court of Appeal addressed the policy concerns in both cases and provided for the expansion of tort law to allow the claim. There is no reason to create a distinction... ${ }^{163}$

Regardless of the ALRI's recommendations, the fact remains that at present, claims advanced by a deceased plaintiff's estate for loss of a chance of earnings are currently

16. Taylor, supra note 22 at 27. 
permissible in Alberta. Until such time as amendments are made to the Survival of Actions Act clarifying the permissibility of claims of this nature, and as Alberta law develops, a more comprehensive body of precedent will develop regarding claims for loss of a chance of earnings. 
Appendix A: 1992 \& 1996 Canadian FAMEX data, 2-person households

\begin{tabular}{|c|c|c|c|c|c|}
\hline \multicolumn{6}{|c|}{ Summany of bousebold expenditure by botusebold and main categories. ${ }^{\prime}$} \\
\hline $\begin{array}{l}\text { Catcgories in } 1992 \\
\text { (t) Represents Fixed Costs and (v) } \\
\text { Represents Variable Costs }\end{array}$ & $\begin{array}{l}\text { Two person } \\
\text { households } \\
\text { based on } 1992 \\
\text { date }\end{array}$ & $\begin{array}{l}\text { Percentage of } \\
\text { total } \\
\text { Expenditure }\end{array}$ & $\begin{array}{l}\text { Two persons } \\
\text { houscholds } \\
\text { based on } 1996 \\
\text { data }\end{array}$ & $\begin{array}{l}\text { Percentage of } \\
\text { total } \\
\text { Expenditure }\end{array}$ & $\begin{array}{l}\text { Categories in } 1996 \\
\text { (f) Represents Fixed Costs and (v) } \\
\text { Represents Variable Costs }\end{array}$ \\
\hline Income Beforc-T2x & \multicolumn{2}{|c|}{$\$ 44,927$} & \multicolumn{2}{|c|}{$\frac{1}{\$ 48,741}$} & Income Before-Tax \\
\hline Shelier (f) (2000-2131) & $\mathbf{5 7 , 6 2 7}$ & $22.3 \%$ & $\mathbf{5 7 , 9 2 5}$ & $22.5 \%$ & Shelter $(\mathfrak{f})(2000-2131)$ \\
\hline $\begin{array}{l}\text { Household operation (f) (row } 2200 \text {. } \\
\text { 2283) }\end{array}$ & $\$ 1,648$ & $4.8 \%$ & $\$ 1,950$ & $5.5 \%$ & Household operation (f) (row 2200-2280) \\
\hline $\begin{array}{l}\text { Ilousehold furnishings and equipment } \\
\text { (f) (row 2300-2498) }\end{array}$ & 51,422 & $4.2 \%$ & $\$ 1,304$ & $3.7 \%$ & $\begin{array}{l}\text { Houschold furnishings and equipment (n) } \\
\text { (row 2301-2498) }\end{array}$ \\
\hline $\begin{array}{l}\text { Mealth care (f) (row } 3000-3063 \text { ) } \\
\text { Transportation (f) (row 2900-2904 \& }\end{array}$ & & $2.5 \%$ & $\$ 1,011$ & $2.9 \%$ & $\begin{array}{l}\text { Health care (f) (row3000-3061) } \\
\text { Transportation (f) (row 2900-2903 \& }\end{array}$ \\
\hline $\begin{array}{l}\text { I ransporiation (t) (row } 29002904 \& 8 \\
\text { 2947) }\end{array}$ & $\$ 2,844$ & $8.3 \%$ & $\$ 2,598$ & $7.4 \%$ & $\begin{array}{l}\text { Iransportation (3) (row } 2900-2903 \& 8 \\
2947)\end{array}$ \\
\hline $\begin{array}{l}\text { Transportation (v) (Total } \\
\text { transportation Cost-(row2900-2904 \& } \\
2947) \text { ) }\end{array}$ & $\$ 2,660$ & $7.8 \%$ & $\$ 2,876$ & $8.2 \%$ & $\begin{array}{l}\text { Transporzation (v) (Total transportation } \\
\text { Cost-(row2900-2904 \& 2947)) }\end{array}$ \\
\hline $\begin{array}{l}\text { Transportation (Total) (row 2900- } \\
\text { 2965) }\end{array}$ & $\$ 5,504$ & $16.1 \%$ & $\$ 5,474$ & $15.5 \%$ & Transportation (Total) (row 2900-2982) \\
\hline $\begin{array}{l}\text { Clothing (v) (row 2500.2879) } \\
\text { Food (v) (row } 1000-1572 \text { ) } \\
\text { Personal care (v) (row 3100-3153) }\end{array}$ & $\begin{array}{l}\$ 1,934 \\
\$ 5,116 \\
\$ 741 \\
\end{array}$ & $\begin{array}{l}5.7 \% \\
15.0 \% \\
2.2 \% \\
\end{array}$ & $\begin{array}{c}\$ 1,815 \\
\$ 5,352 \\
\$ 745 \\
\end{array}$ & $\begin{array}{l}5.1 \% \\
15.2 \% \\
2.1 \% \\
\end{array}$ & $\begin{array}{l}\text { Cloching (v) (row 2500-2879) } \\
\text { Food (v) (row 1000-1572) } \\
\text { Personal care (v) (row 3101 - 3151) }\end{array}$ \\
\hline $\begin{array}{l}\text { Recreation (f) (3200-3271, 3280-3298, } \\
\text { 3301-3318) }\end{array}$ & $\$ 1,314$ & $3.8 \%$ & $\$ 1,489$ & $4.2 \%$ & $\begin{array}{l}\text { Recreation (f) }(3200-3272,3280-3298,3302 \\
3317)\end{array}$ \\
\hline $\begin{array}{l}\text { Recreation (v) (Total recreation - } \\
(3200.3271,3280-3298,3301.3318))\end{array}$ & & $2.4 \%$ & $\$ 985$ & $2.8 \%$ & $\begin{array}{l}\text { Recreation (v) (Total recreation · (3200. } \\
\text { 3272, 3280-3298, 3302-3317n) }\end{array}$ \\
\hline Recreation (Total) (roos 3200-3270) & 23 & 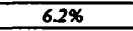 & 2,474 & $7.0 \%$ & Recreation (Total) (roev 3250-3370) \\
\hline $\begin{array}{l}\text { Reading materials and other printed } \\
\text { matter (v) (50\% of Total) (row } 3380 \text { - } \\
3386 \text { ) }\end{array}$ & $\$ 131$ & $0.4 \%$ & $\$ 130$ & $0.4 \%$ & $\begin{array}{l}\text { Reading materials and other printed } \\
\text { matter (v) (50\% of Total) (row 3380-3386) }\end{array}$ \\
\hline $\begin{array}{l}\text { Reading materials and other printed } \\
\text { matter }(0)(50 \% \text { of Total) (3380-3386) }\end{array}$ & $\$ 131$ & $0.4 \%$ & $\$ 130$ & $0.4 \%$ & $\begin{array}{l}\text { Reading materials and other printed } \\
\text { matter }(0)(50 \% \text { of Total) (3380-3386) }\end{array}$ \\
\hline $\begin{array}{l}\text { Reading materials and otber printed } \\
\text { matter (Total) }\end{array}$ & $\$ 26 t$ & $0.8 \%$ & 5259 & $0.7 \%$ & $\begin{array}{l}\text { Reading materials and otber printed } \\
\text { matter (Total) }\end{array}$ \\
\hline $\begin{array}{l}\text { Education (f) (50\% of Total) (row } \\
3390-3400)\end{array}$ & 599 & $0.3 \%$ & $\$ 108$ & $0.3 \%$ & $\begin{array}{l}\text { Education (f) (50\% of Total) (row } 3390 \\
3400)\end{array}$ \\
\hline $\begin{array}{l}\text { Education (v) (50\% of Total) (row } \\
3390-3400 \text { ) }\end{array}$ & $\$ 99$ & $0.3 \%$ & $\$ 108$ & $0.3 \%$ & $\begin{array}{l}\text { Education (v) (50\% of Total) (row } 3390 \\
3400)\end{array}$ \\
\hline Education (Total) (row 3390.3400) & 5198 & $0.6 \%$ & $\$ 215$ & $0.6 \%$ & Education (Total) (roso 3390-3400) \\
\hline $\begin{array}{l}\text { Tobacco products 2nd alcoholis } \\
\text { beverares (v) (row 3500-3515) }\end{array}$ & $\$ 1,448$ & $4.2 \%$ & $\$ 1,169$ & $3.3 \%$ & $\begin{array}{l}\text { Tobacco products and alcoholic beverages } \\
\text { (v) (row } 3501-3520)\end{array}$ \\
\hline Miscellancous (3) (row 3600-3612) & $\$ 1,390$ & $4.1 \%$ & $\$ 1,378$ & $3.9 \%$ & Miscellaneous (Total) (row 3600-3622) \\
\hline Total current consumption & $\$ 30,279$ & $88.7 \%$ & $\$ 31,071$ & $88.1 \%$ & Total current consumption \\
\hline Security (v) (row 3710.3716) & $\$ 2,084$ & $6.1 \%$ & $\$ 2,131$ & $6.0 \%$ & $\begin{array}{l}\text { Personal insurance payments and pension } \\
\text { contributions (v) (row } 3710 \cdot 3716)^{2}\end{array}$ \\
\hline ution $(f)$ (row $3720-3$ & $\$ 1,787$ & $5.2 \%$ & $\$ 2,063$ & $5.8 \%$ & ution (f) (row 3720-3724) \\
\hline Totzl expenditure & $\$ 34,150$ & $100.0 \%$ & $\$ 35,265$ & $100.0 \%$ & Total expenditure \\
\hline$\%$ of Fixed Cost & $56.01 \%$ & N/A & $56.59 \%$ & N/A & $\%$ of Fixed Cost \\
\hline$\%_{0}$ of Variable Cost & $.99 \%$ & $\bar{N} / A$ & & N/A & $\%$ of Variable Cost \\
\hline Total \% of Fixed and Varizble Cost & $100.00 \%$ & N/A & $100.00 \%$ & N/A & Tota $1 \%$ of Fixed and Variable Cost \\
\hline $\begin{array}{l}\text { \% of Total Expenditure Over Total } \\
\text { Income After-tax }\end{array}$ & $95.67 \%$ & N/A & $92.47 \%$ & N/A & $\begin{array}{l}\text { \% of Total Expenditure over Total } \\
\text { Income After-tax }\end{array}$ \\
\hline
\end{tabular}

'Statistics Canada's Family Expenditure in Canada 1992. Catalogue 62.555 occasional Table 17 Pg130-134 and Statistics Canada's

Family Experditure in Canzda 1996, IPS 62F0019. Table 9 (custom tables).

"Alttough named differently, this is equivaleat to the "security" category in the 1992 data. 
Appendix B: 1992 \& 1996 Canadian FAMEX data, 4-person households

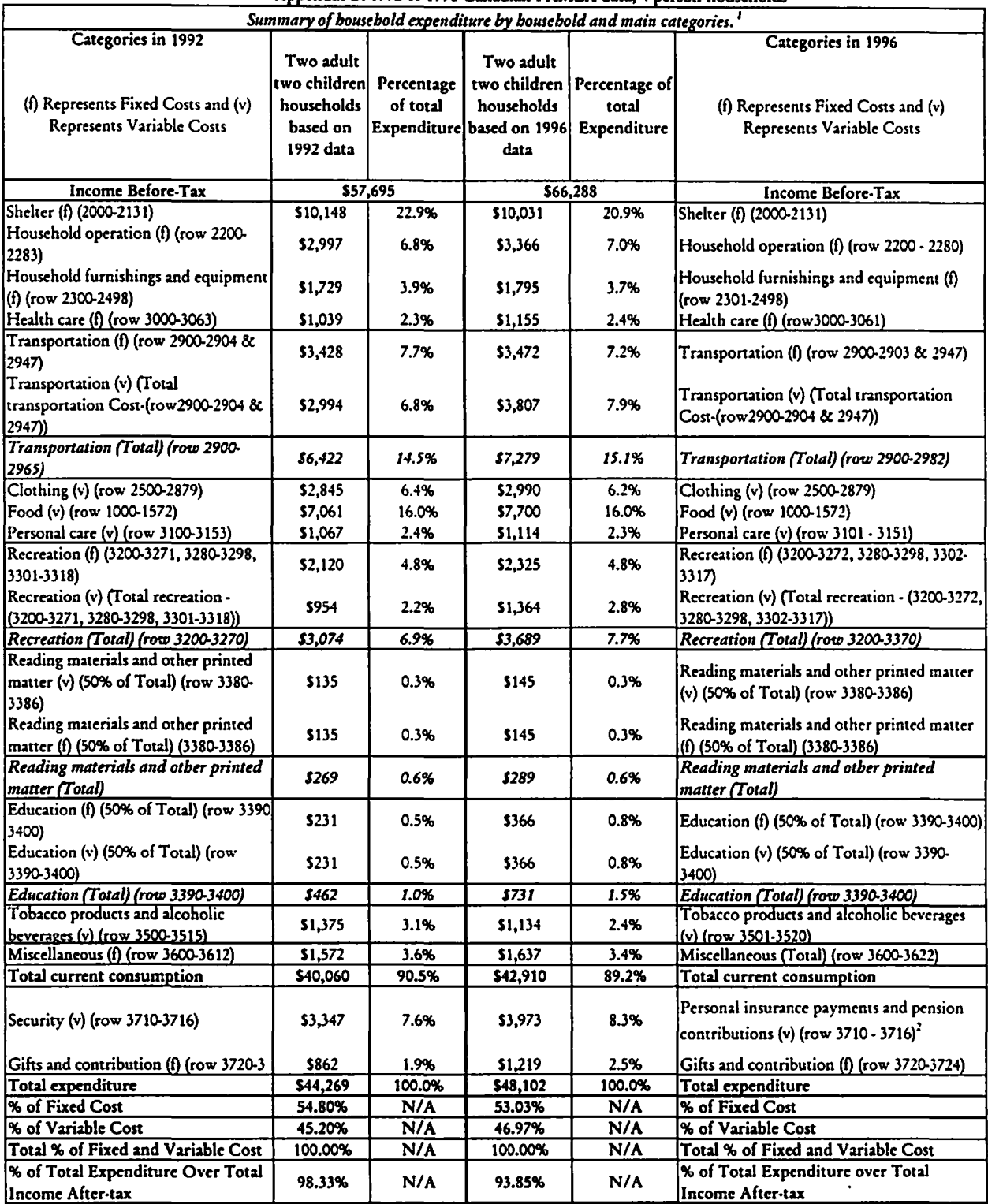

'Statistics Canada's Family Expenditure in Canada 1992. Catalogue 62.555 occasional Table 17 Pg130-134 and Statistics Canada's

Family Expenditure in Canada 1996, IPS 62F0019 -Table 9 (custom tables).

"Although named differently, this is equivalent to the "security" category in the 1992 data. 
Appendix C: 1996 Canadian FAMEX data, 1/2/4 person households with income less than $\$ 15,000$ and between $\$ 15,000$ - \$20,000

\begin{tabular}{|c|c|c|c|c|c|c|c|c|c|c|}
\hline \multirow{2}{*}{$\begin{array}{c}\text { Catceories in } 1996 \text { (1) Represents } \\
\text { Fixed Cost and (v) Represents } \\
\text { Varizble Costs }\end{array}$} & $\begin{array}{c}\text { Incorme less thron } \\
\$ 15,000\end{array}$ & $\begin{array}{c}\text { Xof tozal } \\
\text { Expenditure }\end{array}$ & $\begin{array}{l}\text { Income between } \\
\$ 15,000 \cdot \$ 20,000\end{array}$ & $\begin{array}{c}\text { Xof tots } \\
\text { Expenditure }\end{array}$ & \begin{tabular}{|c|} 
Income less than \\
$\$ 15,000$
\end{tabular} & $\begin{array}{c}\text { Xof totsl } \\
\text { Expenditure }\end{array}$ & $\begin{array}{l}\text { Income between } \\
\$ 15,000 \cdot \$ 20,000\end{array}$ & $\begin{array}{l}\text { Xof total } \\
\text { Expenditure }\end{array}$ & $\begin{array}{c}\text { Incone less than } \\
820,000\end{array}$ & $\begin{array}{l}\text { Xof total } \\
\text { Expenditure }\end{array}$ \\
\hline & \multicolumn{4}{|c|}{ One person Household } & \multicolumn{4}{|c|}{ Two (Adult) Pervon L I louschold } & \multicolumn{2}{|c|}{$\begin{array}{c}4 \text { Person Houschold (2 Adules and } 2 \\
\text { children) }\end{array}$} \\
\hline Ineome before taxes & \multicolumn{2}{|c|}{310,433} & \multicolumn{2}{|c|}{517,132} & \multicolumn{2}{|c|}{$\$ 11,936$} & \multicolumn{2}{|c|}{317,605} & \multicolumn{2}{|c|}{514,803} \\
\hline $\begin{array}{l}\text { Sheterer (i) }(2000-21) \text { I) } \\
\text { Household operation (i) (row } 2200 .\end{array}$ & $\begin{array}{c}34,351 \\
\$ 814\end{array}$ & $\begin{array}{l}36.9 \% \\
6.9 \%\end{array}$ & $\begin{array}{l}35,648 \\
51,028\end{array}$ & $\begin{array}{l}32.9 \% \\
60 \%\end{array}$ & $\begin{array}{l}35,341 \\
31,195\end{array}$ & $\begin{array}{l}29.6 \% \\
6.6 \%\end{array}$ & $\begin{array}{l}35,438 \\
31,332\end{array}$ & $\begin{array}{l}28.0 \% \\
6.996\end{array}$ & $\begin{array}{l}56,639 \\
51,583\end{array}$ & $\begin{array}{l}27.96 \\
6.76\end{array}$ \\
\hline 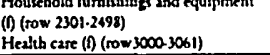 & $\begin{array}{l}5242 \\
5393\end{array}$ & $\begin{array}{l}20 \% \\
3.3 \%\end{array}$ & $\begin{array}{l}3437 \\
\$ 372\end{array}$ & $\begin{array}{l}2.5 \% \\
3.36 \\
\end{array}$ & $\begin{array}{l}\$ 168 \\
\$ 646\end{array}$ & $\begin{array}{l}2.6 \% \\
3.6 \%\end{array}$ & $\begin{array}{l}\$ 611 \\
\$ 782\end{array}$ & $\begin{array}{l}3.1 \% \\
4.06\end{array}$ & $\begin{array}{l}\$ 985 \\
\$ 252\end{array}$ & $\begin{array}{l}0.1 \% \\
.11 \%\end{array}$ \\
\hline $\begin{array}{l}\text { Transponation (i) (row Z300.2003 \& } \\
2947)\end{array}$ & 5203 & 1.74 & 3374 & $2.2 \%$ & 3531 & 2.96 & $\$ 526$ & $2.7 \%$ & $\$ 831$ & $3.5 \times$ \\
\hline $\begin{array}{l}\text { Transponation (v) (Total trasponation } \\
\text { Cost-(rom2000-2003 \& } 29477)\end{array}$ & 8665 & $5.6 \%$ & $\$ 1,795$ & $10.4 \%$ & 38,741 & 9.64 & 31757 & 9.18 & $\$ 2759$ & 11.68 \\
\hline Trensportation (roced) 1000 2900-2982) & 8367 & $7.4 x$ & $\$ 2,169$ & $12.6 \%$ & 32.272 & $12.6 \mathrm{x}$ & 52.284 & $11.8 \mathrm{x}$ & $\frac{25,530}{53,590}$ & $\frac{11.68}{15.1 \mathrm{x}}$ \\
\hline Clothing (v) (row $2300-21$ ) & 5421 & $3.6 \%$ & $\$ 697$ & $4.1 \%$ & 5997 & $3.9 x$ & 5732 & 3.98 & $\$ 1,130$ & $4.7 x$ \\
\hline Food (v) (row 1000 1572) & $\$ 2,295$ & $19.5 \%$ & $\$ 2.595$ & 15.18 & 33,498 & 19.48 & 33.876 & 20006 & $\$ 5,129$ & 21.58 \\
\hline Penoasl care (v) (row 3101 - 3151) & 5261 & $2.2 \%$ & 5393 & 2.36 & 8378 & $2.1 \%$ & 3417 & $2.1 \%$ & $36+6$ & $2.7 x$ \\
\hline 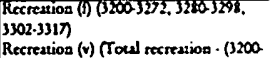 & $\$ 180$ & $1.5 \%$ & $\$ 355$ & $2.1 \%$ & 3563 & $3.1 \%$ & 3375 & $1.9 \%$ & $\$ 1,060$ & 4.5\% \\
\hline 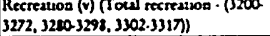 & $\$ 252$ & 2.1\% & $\$ \$ 47$ & $2.6 \%$ & 3373 & $2.1 \mathrm{x}$ & s473 & 2.46 & 8613 & $2.6 x$ \\
\hline 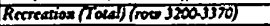 & 5003 & $3.7 x$ & 5802 & $8.7 x$ & 5936 & $5.2 x$ & 5843 & $1.5 x$ & 81.673 & $7.0 x$ \\
\hline Readiag manerials and ol ser priased & & & & & & & & & & \\
\hline $\begin{array}{l}\text { matter (v) (SO\% of Toral) (row } 33600 \\
\text { Reading materials and olbet prinited }\end{array}$ & 350 & 0.48 & 573 & $0.4 \%$ & 579 & $0.4 \%$ & 375 & $0.4 \%$ & $\$ 58$ & $0.2 \%$ \\
\hline matter (1) (50\% of Tota) (3350-3386) & 350 & $0.4 x$ & 373 & $0.4 \%$ & 579 & $0.4 \%$ & 575 & $0.4 \%$ & 858 & $0.2 \times$ \\
\hline $\begin{array}{l}\text { Reading maserials axd ochor prixted } \\
\text { matter (Total) }\end{array}$ & $\$ 100$ & $0.8 \%$ & $\$ 147$ & $0.9 x$ & ssss & $0.9 x$ & siso & $0.8 \times$ & sins & $0.5 \mathrm{x}$ \\
\hline Eductition (i) (SBOx of Tora) (row 3390 & 49 & & 81 & $0 \%$ & 0 & 00 & 0 & $00 \%$ & 5 & $10 \%$ \\
\hline Eduction (v) (50\% of Total) (row 3320 & 349 & 0.48 & 339 & 0.28 & 80 & 0.068 & 30 & 0.076 & 2288 & 100 \\
\hline & 549 & $0.4 \%$ & 539 & $0.2 \%$ & so & $0.0 \%$ & so & $0.0 \%$ & $\$ 228$ & $1.0 \%$ \\
\hline 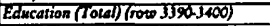 & 598 & $0.8 \times$ & 578 & $0.5 \mathrm{x}$ & 50 & $0.0 x$ & 50 & $0.0 x$ & 5856 & $1.9 \times$ \\
\hline Tobacco products and akobolic & & & & & & & & & & \\
\hline beverizes (v) (row 3501. 3520) & 5443 & $3.8 \%$ & $\$ 563$ & $3.3 \%$ & $\mathbf{5 8 6 2}$ & $4.2 \%$ & 5899 & $4.6 \%$ & 5687 & $2.9 \%$ \\
\hline Miscellipeous (Tota) (rov $3600-3622)$ & 3352 & $30 \%$ & 3530 & $3.1 \%$ & $\$ 512$ & 2.856 & 5807 & $4.2 \%$ & 5475 & $20 x$ \\
\hline Total current consumption & $\$ 11,071$ & $93.9 \%$ & 515,659 & $99.1 \%$ & 816,962 & $93.9 \%$ & $5,8,195$ & $93.7 \times$ & 523,361 & $98.1 \%$ \\
\hline Personal insurance payments and & & & & & & & & & & \\
\hline $\begin{array}{l}\text { pension conaributions (v) (row } 3710 \text {. } \\
3716 \text { ) }\end{array}$ & $\$ 123$ & $1.0 \%$ & $\$ 582$ & $3.4 \%$ & $\$ 201$ & $1.1 \%$ & 5394 & $2.0 \%$ & 5267 & $1.1 \%$ \\
\hline $\begin{array}{l}\text { 3716) } \\
\text { Gifs and contribution (1) (row } 3720.3722\end{array}$ & $\$ 399$ & $5.1 \%$ & 5953 & $5.5 \%$ & $\$ 894$ & $4.9 \%$ & 5821 & $4.2 \%$ & 5173 & $0.7 x_{0}$ \\
\hline Total expenditure & 511,794 & $100.0 \%$ & $\$ 17,194$ & $100.0 \%$ & 518,056 & $100.0 \%$ & 519,410 & $100.0 \%$ & 523,802 & $100.0 x$ \\
\hline \%or Fixed Cost & $61.34 \%$ & N/A & $58.22 \%$ & N/A & $56.64 x$ & N/A & $53.47 *$ & N/A & $31.61 \%$ & N/A \\
\hline$\%_{0}$ of Variable Cost & $38.66 \%$ & N/A & $41.78 \%$ & N/A & $43.36 \%$ & $\mathrm{~N} / \mathrm{A}$ & $44.53 \%$ & $\mathbf{N} / \mathbf{A}$ & $8.39 \%$ & N/A \\
\hline Tolal \& of Fixed and Variable Cost & $100.00 \%$ & N/A & $100.00 \%$ & N/A & $100.00 \%$ & $\mathbf{N} / \mathbf{A}$ & $100.00 \%$ & $\mathrm{~N} / \mathrm{A}$ & $100.00 x$ & N/A \\
\hline $\begin{array}{l}\text { Xof Total Expendizure over Totel } \\
\text { Income Afier-tux }\end{array}$ & HS.BAX & N/A & $109.68 x$ & N/A & $15336 \mathrm{x}$ & N/A & 113.85x & N/A & $161.64 \times$ & N/A \\
\hline
\end{tabular}




\section{APPENDIX D: \\ SPOUSAl SupPort DATA FOR a DEDUCTION \\ SIMILAR TO THE ONE USED IN BROOKS V. STEFURA}

Using the methodology accepted by the court in Brooks to assess loss of dependency for the deceased's spouse in the context of inevitable divorce between the parties, one is required to assess the spousal support that the surviving spouse would have received from the deceased but for the accident.

There is no magic formula for calculating spousal support, and as has been mentioned by Payne, "[t]he right to, quantum and duration of spousal support must be determined by the judicial exercise of discretion in light of the particular circumstances of the case." 164 The seminal judgment guiding spousal support determinations in Canada today is Moge v. Moge, ${ }^{165}$ wherein L'Heureux-Dube J. commented:

In all events, whether judicial notice of the circumstances generally encountered by spouses at the dissolution of marriage is to be a formal part of the trial process or whether such circumstances merely provide the necessary background information, it is important that judges be aware of the social reality in which support decisions are experienced when engaging in the examination of the objectives of the [Divorce] $A c$. $^{\text {16t }}$

Other authors have pointed out that "[t]he starting point seems to be that the dependant who is entitled to support should be allowed to maintain a lifestyle similar to that of the payor." 167

By way of comparison, the different results between spousal support awards in uncontested divorce files and reported divorce cases are show in Table D-1 (all values are given in 1999 dollars). ${ }^{168}$

J.D. Payne, Payne on Divorce, 3d ed. (Toronto: Carswell, 1993). See also Moge v. Moge (1992), 43 R.F.L. (3d) 345 (S.C.C.) [hereinafter Moge].

Moge, ibid. The reader will note that Bracklow v. Bracklow (1999), 169 D.L.R. (4th) 577 (S.C.C.), was decided after this article was written.

Moge, ibid. at 874.

J.G. Mcleod \& A.A. Mamo, Annual Review of Family Law (Toronto: Carswell, 1994).

The 1988 amounts given in the Brown study are adjusted to 1999 dollars using Statistics Canada, Annual Estimates of Employment, Earnings, and Hours, 1984-1996 (October \& November 1998), Industrial Aggregate (SIC 000-999 index). 
TABLE D-1:

SPOUSAL SUPPORT AWARDS IN UNCONTESTED DIVORCES AND REPORTED DIVORCE CASES, $1999 \${ }^{1(1)}$

\begin{tabular}{|l|l|l|}
\hline Variable & $\begin{array}{l}\text { Uncontested Divorce } \\
\text { Files* }\end{array}$ & Reported Cases** \\
\hline $\begin{array}{l}\text { Average lump-sum spousal support award } \\
\text { (all marriages) }\end{array}$ & $\$ 15,082$ & $\$ 31,350$ \\
\hline $\begin{array}{l}\text { Average time-limited spousal support award } \\
\text { (all marriages) }\end{array}$ & $\$ 866 /$ month & $\$ 1,272 /$ month \\
\hline $\begin{array}{l}\text { Average time-limited spousal support award } \\
\text { (marriages over 15 years in duration) }\end{array}$ & $\$ 945 /$ month & $\begin{array}{l}\$ 860 / \text { month }(15-20 \text { years of } \\
\text { marriage) } \$ 1,283 / \text { month }(21+ \\
\text { years of marriage) }\end{array}$ \\
\hline $\begin{array}{l}\text { Average permanent spousal support award } \\
\text { (all marriages) }\end{array}$ & $\$ 450 /$ month & $\$ 1,949 /$ month \\
\hline $\begin{array}{l}\text { Average permanent spousal support award } \\
\text { (marriages over } 15 \text { years in duration) }\end{array}$ & $\$ 352 /$ month & $\$ 2,158 /$ month \\
\hline $\begin{array}{l}\text { Average duration of time-limited award (all } \\
\text { marriages) }\end{array}$ & 23.9 months & 22.9 months \\
\hline $\begin{array}{l}\text { Average annual gross salary of husband at } \\
\text { date of separation (all marriages) }\end{array}$ & $\$ 53,823$ & $\$ 122,063$ \\
\hline $\begin{array}{l}\text { Average annual gross salary of husband at } \\
\text { date of separation (marriages over } 15 \text { years } \\
\text { in durations) }\end{array}$ & $\$ 71,352$ & Not Available \\
\hline $\begin{array}{l}\text { Average annual gross salary of wife at date } \\
\text { of separation (all marriages) }\end{array}$ & $\$ 16,496$ & $\$ 20,106$ \\
\hline $\begin{array}{l}\text { Average annual gross salary of wife at date } \\
\text { of separation (marriages over 15 years in } \\
\text { duration) }\end{array}$ & $\$ 13,896$ & Nvailable \\
\hline
\end{tabular}

- A random sample of all uncontested divorces filed with the Alberta Court of Queen's Bench, Calgary between 1 January 1987 and 1 January 1988.

** A random sample of all reported divorce cases in Canada between 11 June 1986 and 14 March 1988.

A study by C.L. Brown, The Economics of Compensation at Divorce, ${ }^{170}$ also found that the longer the marriage and the higher the husband's salary, the greater the likelihood of a permanent award, and 72 percent of time-limited awards corresponded to marriages lasting over ten years. ${ }^{171}$

As the Alberta Court of Appeal has pointed out, the determination of spousal support awards is essentially a function of the evidence available. ${ }^{172}$ Calgary, 1988). 


\section{APPENDIX E: \\ Child Support Data for a Deduction Similar to the ONE USED IN BROOKS V. STEFURA}

Using the methodology accepted by the court in Brooks to assess loss of dependency for the deceased's children in the context of inevitable divorce between the children's parents, one is referred to the Federal Child Support Guidelines. Although Brooks was an Alberta case, the methodology using child support as an indicator of dependency loss for children can be easily applied across Canada as the Guidelines contain province-specific tables.

In Simon v. Wright, ${ }^{173}$ the court awarded an eleven-year old girl damages in the amount of $\$ 500.00$ per month as benefits from the time of her father's death until her 23rd birthday. Although her father had been separated from her mother at the time of the accident, the court awarded the benefits based on the fact that she had a close relationship with her father. In Frank v. Cox, ${ }^{174} \$ 5,000.00$ was awarded to an 18year-old child for loss of dependency; in this case, the court offered no explanation of why the dependency period was extended past the age of 18 .

One will also note Belzil J.'s comment in Brooks that "[i]n my view, a Court assessing child support would assess $\mathbf{s .} 7$ extraordinary expenses in the amount of $\$ 50$ per child for the same period." 175 As per Brooks, this amount is not subject to a tax gross-up. 